\title{
Multiple origins of the Paleogene natural gases and effects of secondary alteration in Liaohe Basin, northeast China: insights from
}

\section{the molecular and stable isotopic compositions}

\author{
Shipeng Huang ${ }^{a *}$, Ziqi Feng ${ }^{a}$, Tuan Gu ${ }^{\mathrm{b}}$, Deyu Gong ${ }^{\mathrm{a}}$, Weilong Peng ${ }^{\mathrm{a}}$, Miao Yuan ${ }^{\mathrm{a}}$ \\ a. Research Institute of Petroleum Exploration \& Exploitation, PetroChina, Beijing, 100083 \\ b. Liaohe Oilfield Company, PetroChina, Panjin, Liaoning Province, 124000 \\ Corresponding author: shipenghuang@petrochina.com.cn
}

\begin{abstract}
The molecular and isotopic $(\mathrm{C}$ and $\mathrm{H})$ compositions of Paleogene [Shahejie Formation $\left(\mathrm{E}_{2-3} \mathrm{~s}\right)$ and Dongying Formation $\left.\left(\mathrm{E}_{3} \mathrm{~d}\right)\right]$ natural gases from 11 new gas samples as well as the data of 71 gases published from previous studies in the Liaohe Basin were analyzed, and the results were considered in combination with geochemical and distribution characteristics of the source rocks. The genetic type, gas-source correlation and secondary alteration of the natural gases were studied in detail, and the source rock maturities of the gases were estimated. The following conclusions were reached: (1) with the exception of dry gases in the major part of the third member of the Shahejie Fm. $\left(\mathrm{E}_{2} \mathrm{~s}^{3}\right)$ reservoirs, the gases in other reservoirs are mainly wet; (2) variable carbon and hydrogen isotopes of the alkane gases are observed in different reservoirs of the basin with $\delta^{13} \mathrm{C}_{1}$ values ranging from $-60.7 \%$ to $-34.2 \%$, $\delta^{13} \mathrm{C}_{2}$ from $-47.3 \%$ to $-22.3 \%$, $\delta^{2} \mathrm{H}_{\mathrm{CH} 4}$ from $-261 \%$ to $-188 \%$, and $\delta^{2} \mathrm{H}_{\mathrm{C} 2 \mathrm{H} 6}$ from $-269 \%$ to $-148 \%$; (3) the natural gases of the basin are of multiple origins, and mixing of thermogenic and microbial is observed - the mixing ratio in the first member of the Shahejie Fm. $\left(\mathrm{E}_{3} \mathrm{~s}^{1}\right)$ is the highest among all the reservoirs; (4) gases of different reservoirs suffered varying extents of biodegradation, which caused partial reversal of the carbon isotope series of methane and its homologues $\left(\delta^{13} \mathrm{C}_{1}<\delta^{13} \mathrm{C}_{2}\left\langle\delta^{13} \mathrm{C}_{3}\right\rangle\right.$ $\left.\delta^{13} \mathrm{C}_{4}\right)$; the reversal of the gases in the shallow reservoirs $\left(\mathrm{E}_{3} \mathrm{~s}^{1}\right.$ and $\left.\mathrm{E}_{3} \mathrm{~d}\right)$ is greater, while those in the deep reservoir $\left(\mathrm{E}_{2} \mathrm{~s}^{3}\right)$ is less; (5) humic natural gases of the ED were mainly generated by source rocks at early maturity, while the sapropelic ones of the ED and WD were generated during the mature and high mature stages; (6) both the source rocks of $\mathrm{E}_{2} \mathrm{~s}^{3}$ and $\mathrm{E}_{2} \mathrm{~s}^{4}$ strata could contribute to the gas reservoirs of $\mathrm{E}_{2} \mathrm{~s}^{3}$ and $\mathrm{E}_{2} \mathrm{~s}^{1}$ in the west depression. Sapropelic gases in east depression were generated by $\mathrm{E}_{2} \mathrm{~s}^{3}$ source rocks, while the other gases reservoired in the $\mathrm{E}_{2} \mathrm{~s}^{3}, \mathrm{E}_{3} \mathrm{~s}^{1}$, and $E_{3} d$ strata are probably sourced from the source rock strata of $E_{2} s^{3}$ and $E_{3} s^{1-2}$.
\end{abstract}


Keywords: Biodegradation; Origin; Gas-source correlation; Liaohe Basin; Mixing; Migration; Paleogene

\section{Introduction}

Natural gases have two genetic types: microbial or thermogenic. Microbial gas, which is mainly methane, is a product of biogeochemical processes associated with the remineralisation of labile organic matter at temperatures $<80{ }^{\circ} \mathrm{C}$ by communities of microbes (Whiticar et al., 1986; Schoell, 1988; Whiticar, 1999; Huang et al., 2014). Microbial gas is characterized by a high dryness coefficient with $\mathrm{C}_{1} / \mathrm{C}_{1-5}>0.95$ and is enriched in ${ }^{12} \mathrm{C}$ with $\delta^{13} \mathrm{C}_{1}<-55 \%$, and it accounts for more than 20\% of the world's gas (Rice and Claypool, 1981; Rice, 1993) and is considered to be one of the most important gas sources of gas hydrate (Collett, 2002). Thermogenic gas is generated by the degradation or cracking of organic matter (kerogen and oil) under high thermal stress (Stahl, 1977; Schoell, 1983; Dai et al., 1992). Thermogenic gas can be divided into two types: humic gas (generated by humic organic matter with kerogen type III) and sapropelic gas (generated by sapropelic organic matter with kerogen type I-II). The $\delta^{13} \mathrm{C}_{1}$ value of thermogenic gas is often larger than $-50 \%$. When generated by a low maturity source rock, thermogenic gas is typically rich in heavy alkane gases $\left(\mathrm{C}_{2-5}\right)$; when generated by high-maturity source rocks, it has a high dryness coefficient. The carbon isotope values of the alkane gases of humic gas indicate enrichment in ${ }^{13} \mathrm{C}$ compared with those of sapropelic gases of similar maturity (Stahl, 1977; Dai et al., 1992; Galimov, 2006). The molecular and isotopic values of the gases can be affected by secondary alteration, including mixing, migration and biodegradation (Schoell, 1980, 1983; James, 1990; Dai et al., 1992; Whiticar, 1999; Martini et al., 2008; Hao et al., 2008; Osborn and Mclntosh, 2010; Liu et al., 2013). Thus, isotopic values must be used to reliably identify the origins, sources and maturities of the gases.

Many previous works have studied the genetic types of the natural gases in the Liaohe Basin, and various genetic types (e.g. microbial gas, sapropelic gas, humic gas and mixed gas) have been identified (Xu et al., 1993; Liu et al., 1993; Zhang et al., 2002; Li et al., 2011; Huang et al., 2014; Li et al., 2015). Many of these previous studies focused on one oil and gas field or a local study area in the Liaohe Basin. However, the geochemical characteristics of the gases throughout the entire basin have not been deeply studied, and little has been reported on the effects of biodegradation, migration and mixing on the gases produced in different reservoirs of different 
depressions. In this study, the molecular and stable isotopic compositions of the gases of the entire basin were studied comprehensively in combination with the Paleogene geological characteristics to determine the origins and sources of the gases in different reservoirs and depressions along with the effects of secondary alteration (e.g. biodegradation, migration and mixing). The findings of this work can significantly improve the understanding of the petroleum system and are beneficial to petroleum exploration in the Paleogene strata of the Liaohe Basin.

\section{Geological setting}

The geological setting of the petroleum systems of the Liaohe Basin has been summarized by numerous authors (e.g., Koopmans et al., 2002; Tuo et al., 2003; Fuhrmann et al., 2004; Huang et al., 2004; Hu et al., 2005; Li et al., 2013; Gu, 2016). The Liaohe Basin, located in northeast China, is one of the secondary tectonic elements of the Bohai Bay Basin groups (Fig. 1a). The Liaohe Basin is bounded by several structural elements: the Yanliao fold belt to the west, the Inner Mongolia axis to the north, the Liaodong anticline to the east, and the Liaodong Bay and Bohai Sea to the south (Fig. 1b). The basin is a Cenozoic rift basin developed after Mesozoic rifting and spans approximately $65 \mathrm{~km}$ in width and $470 \mathrm{~km}$ in length (Hu et al., 2005). The basin is subdivided into six structural units: the western uplift, central uplift, western depression (WD), eastern depression (ED), and the da'mintun depression. The WD and ED are separated by the central uplift (Fig. 1b). The three depressions were mostly isolated from each other during their development, and the tectonic and sedimentary differences among them caused the differences in their petroleum systems (Xu et al., 1993).

The thickness of the Cenozoic sedimentary layer is primarily $3000-4000 \mathrm{~m}$, although some deep parts contain up to $6000 \mathrm{~m}$ of sediments. The Paleogene sediments mainly consist of clastic rocks with a few carbonates and volcanic horizons (Fig. 2). The Paleogene contains three formations, the Fangshenpao Fm. $\left(E_{1} f\right)$, Shahejie Fm. $\left(E_{2-3} \mathrm{~s}\right)$ and Dongying Fm. $\left(E_{3} d\right)(F i g .2,3)$ and the oil and gas are mainly preserved in the Shahejie Fm. (Fig. 2) (Hu et al., 2005; Li et al., 2013). The Shahejie Fm. can be subdivided into four members; from oldest to youngest, they are the fourth member $\left(\mathrm{E}_{2} \mathrm{~s}^{4}\right)$, the third member $\left(\mathrm{E}_{2} \mathrm{~s}^{3}\right)$, the second member $\left(\mathrm{E}_{3} \mathrm{~s}^{2}\right)$ and the first member $\left(\mathrm{E}_{3} \mathrm{~s}^{1}\right)$. The ED was undergoing erosion during the $\mathrm{E}_{2} \mathrm{~s}^{4}$ depositional period, and the $\mathrm{E}_{2} \mathrm{~s}^{4}$ strata were only deposited in the WD. The sedimentary environment of the basin was deep-lake or semi-deep-lake during the $\mathrm{E}_{2} \mathrm{~s}^{3}$ depositional period, and the $\mathrm{E}_{2} \mathrm{~s}^{3}$ strata was distributed widely in 
the basin (Zhang et al., 2002). Several source rocks developed in the basin (Fig. 2, Table 1); $\mathrm{E}_{2} \mathrm{~s}^{4}$ and $\mathrm{E}_{2} \mathrm{~s}^{3}$ are the major source units (Xu et al., 1993; Zhang et al., 2002; Hu et al., 2005; Li et al., 2013; Huang et al., 2014). The source rocks are mudstones and shales containing high contents of organic matter. Coal seams are also found in the $\mathrm{E}_{2} \mathrm{~s}^{3}$ strata, and the vitrinite reflectance values $\left(\mathrm{VR}_{\mathrm{o}}\right)$ of the ones in the $\mathrm{WD}$ are from $0.5 \%$ to $1.3 \%$, while the ones in the $\mathrm{ED}$ are from $0.7 \% \sim 1.3 \%$. The $\mathrm{E}_{2} \mathrm{~s}^{4}$ source rocks are sapropelic with mainly type II-I kerogen (oil prone) and their $\mathrm{VR}_{\mathrm{o}}$ ranges from $0.5 \%$ to $2.0 \%$. The $\mathrm{E}_{2} \mathrm{~s}^{4}$ source rocks of WD began to generate hydrocarbon in the middle period during $\mathrm{E}_{2} \mathrm{~s}^{3}$ deposition, and reach maturity (enter oil window) at the end of $\mathrm{E}_{2} \mathrm{~s}^{3}$ period, and major part of the source rocks are mature to over mature stage at present. The kerogen types of the $\mathrm{E}_{2} \mathrm{~s}^{3}$ source rock are different in the two depressions of the WD and ED. The former are mainly sapropelic with type I-II kerogen, whereas the latter are mainly humic with type III-IIkerogen (gas prone). The $\mathrm{E}_{2} \mathrm{~s}^{3}$ source rocks of WD entered the oil window at the late period of the $\mathrm{E}_{2} \mathrm{~s}^{3}$, and most are mature to highly mature at present. (Xu et al., 1993; Zhang et al., 2002; Koopmans et al., 2002; Fuhrmann et al., 2004; Hu et al., 2005). In general, the evolution stages of the same source rock strata in the WD are earlier than the ones of ED, causing the present maturity values to be much greater than the latter. As a typical rifting basin, faults are very developed in the Liaohe basin (Fig.3), and hydrocarbons generated by the source rocks of different strata can migrate along the sands and the faults and accumulate in the reservoirs.

\section{Material and methods}

Eleven free gas samples were collected from the Liaohe Basin, and the molecular and stable isotopic compositions were calculated at the RIPED Key Laboratory of Petroleum Geochemistry (KLPG) of PetroChina. The previously published geochemical data for 71 wells of the basin were also used in this paper. The geochemical data are listed in Tables 2 and 3.

\subsection{Analysis of molecular composition}

An Agilent 6890N gas chromatograph (GC) equipped with a thermal conductivity detector (TCD) was used to determine the molecular composition of gas samples. The hydrocarbon gas components were separated using a capillary column (PLOT $\mathrm{Al}_{2} \mathrm{O}_{3}, 30 \mathrm{~m} \times 0.32 \mathrm{~mm} \times 20 \mu \mathrm{m}$ ). Helium was used as the carrier gas with a rate of $40 \mathrm{~mL} / \mathrm{min}$. The inlet temperature was set at $150{ }^{\circ} \mathrm{C}$, and the TCD temperature was $200{ }^{\circ} \mathrm{C}$. The initial oven temperature was maintained at 
$40{ }^{\circ} \mathrm{C}$ for $7.5 \mathrm{~min}$ isothermally and then rose from $40{ }^{\circ} \mathrm{C}$ to $90{ }^{\circ} \mathrm{C}$ at $15^{\circ} \mathrm{C} / \mathrm{min}$, finally from $90{ }^{\circ} \mathrm{C}$ to $180{ }^{\circ} \mathrm{C}$ at $6{ }^{\circ} \mathrm{C} / \mathrm{min}$. Peak areas were integrated, and the mole percent of the compositions is given. The precision of the analysis is $0.01 \%$.

\subsection{Stable carbon and hydrogen isotopic analysis}

International standard gas samples NG1 (humic gas), NG2 (biogas), and NG3 ( sapropelic gas) were co-developed by the Gas Accumulation and Development Laboratory, PetroChina Research Institute of Petroleum Exploration and Development (Langfang Branch) China, and foreign laboratories from USA and Germany (Dai et al., 2012), and were used for the carbon and hydrogen isotope ratio analysis here. The calibrated consensus values of NG1, NG2 and NG3 are:

NG1 (humic gas):

Methane: $\delta^{13} \mathrm{C}_{\mathrm{VPDB}}=-34.18 \% \pm 0.10 \%, \delta^{2} \mathrm{H}_{\mathrm{VSMOW}}=-185.1 \%$ \% $\pm 1.2 \%$

Ethane: $\delta^{13} \mathrm{C}_{\mathrm{VPDB}}=-24.66 \%$ \% $\pm .11 \%, \delta^{2} \mathrm{H}_{\mathrm{VSMOW}}=-156.3 \%$ \% $\pm 1.8 \%$

Propane: $\delta^{13} \mathrm{C}_{\mathrm{VPDB}}=-22.21 \% \pm \pm 0.11 \%, \delta^{2} \mathrm{H}_{\mathrm{VSMOW}}=-143.6 \% 0 \pm 3.3 \%$

$i$-Butane: $\delta^{13} \mathrm{C}_{\mathrm{VPDB}}=-21.62 \% \pm 0.12 \%$

$n$-Butane: $\delta^{13} \mathrm{C}_{\mathrm{VPDB}}=-21.74 \% \pm 0.13 \%$

$\mathrm{CO}_{2}: \delta^{13} \mathrm{C}_{\mathrm{VPDB}}=-5.00 \% \pm 0.12 \%$

NG2 (biogas):

Methane: $\delta^{13} \mathrm{C}_{\mathrm{VPDB}}=-68.89 \% \pm 0.12 \%, \delta^{2} \mathrm{H}_{\mathrm{VSMOW}}=-237.0 \% \pm \pm 1.2 \%$

NG3 (sapropelic gas):

Methane: $\delta^{13} \mathrm{C}_{\mathrm{VPDB}}=-43.61 \% \pm 0.09 \%, \delta^{2} \mathrm{H}_{\mathrm{VSMOW}}=-167.6 \% \pm \pm 1.0 \%$

Ethane: $\delta^{13} \mathrm{C}_{\mathrm{VPDB}}=-40.24 \% \pm \pm 0.10 \%, \delta^{2} \mathrm{H}_{\mathrm{VSMOW}}=-164.1 \%$ $\pm 2.4 \%$

Propane: $\delta^{13} \mathrm{C}_{\mathrm{VPDB}}=-33.79 \% \pm 0.09 \%, \delta^{2} \mathrm{H}_{\mathrm{VSMOW}}=-138.4 \%$ \% $\pm 3.0 \%$

An on-line method was used to measure the carbon and hydrogen isotopic compositions of natural gas. The stable carbon and hydrogen isotopic values are reported in ' $\delta$ ' notation in per mil (\%). The $\delta^{13} \mathrm{C}$ and $\delta^{2} \mathrm{H}$ values were measured and expressed relative to the Vienna Peedee Belemnite (VPDB) and Vienna Standard Mean Ocean Water (VSMOW) scale, respectively. The measurement tolerances of the carbon and hydrogen isotopic values are $\pm 0.3 \%$ and $\pm 3 \%$, respectively. Specific procedures of the measurement are as follows. 
Stable carbon isotope ratios were determined using a Finnigan MAT Delta S mass spectrometer interfaced with an HP 5890II chromatograph. The gas components were separated on the gas chromatograph in a stream of helium, converted into carbon dioxide in a combustion interface, and then introduced into the mass spectrometer. Alkane gases $\left(\mathrm{C}_{1}-\mathrm{C}_{5}\right)$ and carbon dioxide were initially separated using a fused silica capillary column (PLOT, $30 \mathrm{~m} \times 0.32 \mathrm{~mm}$ ). The helium was used as the stream gas with flow rate of $10 \mathrm{~mL} / \mathrm{min}$. The inlet temperature was $150{ }^{\circ} \mathrm{C}$, the temperature of oxidation oven was $950{ }^{\circ} \mathrm{C}$. The $\mathrm{GC}$ oven temperature was ramped from $35{ }^{\circ} \mathrm{C}$ to $80{ }^{\circ} \mathrm{C}$ at $8{ }^{\circ} \mathrm{C} / \mathrm{min}$ and then to $260{ }^{\circ} \mathrm{C}$ at $5{ }^{\circ} \mathrm{C} / \mathrm{min}$; the oven maintained this final temperature for 10 min. Each gas sample was analyzed three times, and the average was calculated.

Hydrogen isotopic ratio was determined on a MAT253 isotopic mass spectrometer (Thermo Fisher Scientific) equipped with a Trace GC UltraTM using the gas chromatography pyrolysis interface and the water removal device. The helium was used as the stream gas, and an HP-PLOT Q column $(30 \mathrm{~m} \times 0.32 \mathrm{~mm} \times 20 \mu \mathrm{m})$ was used with flow rate of $1.4 \mathrm{~mL} / \mathrm{min}$. The inlet temperature was set at $180{ }^{\circ} \mathrm{C}$. The gas was injected into the gas chromatograph in split injection model (split ratio $=1: 7)$. The oven temperature was initially set at $40{ }^{\circ} \mathrm{C}$, and maintained for 5 min, ramped to $40-80{ }^{\circ} \mathrm{C}$ at $5{ }^{\circ} \mathrm{C} / \mathrm{min}, 80-140{ }^{\circ} \mathrm{C}$ at $10{ }^{\circ} \mathrm{C} / \mathrm{min}$, and $140-260{ }^{\circ} \mathrm{C}$ at $30{ }^{\circ} \mathrm{C} / \mathrm{min}$. The pyrolysis oven temperature was $1450{ }^{\circ} \mathrm{C}$.

\section{Results}

\subsection{Molecular composition of natural gas}

The Paleogene natural gases are dominated by methane with various contents of heavy alkane gases $\left(\mathrm{C}_{2}-\mathrm{C}_{5}\right)$ (Tables 2 and 4, Fig.4). The average content of methane in the ED decreases from the $E_{2} s^{3}$ to the $E_{3} s^{1}$ reservoirs and then to the $E_{3} d$ reservoirs (Table 4, Fig. 4a); the average content of heavy alkane gases shows the opposite trend (Table 4). In general, much more variable contents of the molecular compositions are found in the ED than the ones of WD, especially for the ones of methane and ethane (Fig.4)

The dryness coefficients $\left(\mathrm{C}_{1} / \mathrm{C}_{1-5}\right)$ of the gases in the same reservoirs of the Liaohe basin decrease with increasing depth (Fig. 5a). According to Schoell (1980) a gas may be classified as dry if it exhibits a dryness coefficient greater than 0.95. The gases preserved in the $E_{3} \mathrm{~d} F m$. 
reservoir are mainly wet gases. The gases of the $\mathrm{E}_{3} \mathrm{~s}^{1}$ reservoir in the WD are slightly dryer than those of $\mathrm{E}_{3} \mathrm{~s}^{1}$ reservoir in the ED. The gases in the $\mathrm{E}_{2} \mathrm{~s}^{3}$ reservoirs of the ED are mainly dry and the ones of WD are mainly wet (Table 4).

Carbon dioxide and nitrogen are the main non-hydrocarbon gases, and the content of each is generally lower than $5 \%$ (Tables 2 and 4). In general, the content of nitrogen is higher than that of carbon dioxide. The contents of the non-hydrocarbons in the WD are higher than those in the ED.

\subsection{Stable isotopic composition of natural gas}

\subsubsection{Carbon isotopes of the alkane gases and the carbon dioxide}

No apparent correlations have been found between the carbon isotopic compositions of the alkane gases and the depth except for the ones of the $\delta^{13} \mathrm{C}_{2}$ values of the ED (Fig.5). In the individual fields trends are more obvious. The $\delta^{13} \mathrm{C}_{1}$ values of Dongying Fm. in the Niuju field show good positive correlation with depth. The $\delta^{13} \mathrm{C}_{2}$ and $\delta^{13} \mathrm{C}_{3}$ values of Dongying Fm. and $\mathrm{E}_{3} \mathrm{~s}^{1}$ in the Rongxingtun field of ED also show positive correlations. Carbon isotopic compositions of the alkane gases reservoired in $\mathrm{E}_{2} \mathrm{~s}^{3}$ in Lengjiapu oil field show no trend at all with depth but generally $\delta^{13} \mathrm{C}_{1}$ is less scattered than in $\mathrm{E}_{3} \mathrm{~s}^{1}$ of Lengjiapu oil field.

Significant variations are observed in the carbon isotopic compositions of the natural gases in the Liaohe Basin, particularly for the gases in the $\mathrm{E}_{3} \mathrm{~s}^{1}$ reservoirs throughout the entire basin and for the gases in the $\mathrm{E}_{2} \mathrm{~s}^{3}$ reservoirs in the ED (Tables 3 and 4; Fig. 5 and 6). The differences among the $\delta^{13} \mathrm{C}$ values of methane in different gases are the most obvious. The $\delta^{13} \mathrm{C}_{2-4}$ values of different gases also have a large range. The carbon isotope curves of the alkane gases in the $E_{3} d$ reservoirs of the ED are also very similar, even though their $\delta^{13} \mathrm{C}_{1}$ values differ by up to $10 \%$.

Carbon isotope reversals between propane and butane $\left(\delta^{13} \mathrm{C}_{3}>\delta^{13} \mathrm{C}_{4}\right)$ are common in the Paleogene gases of the Liaohe Basin. These reversals are only observed in the $\delta^{13} \mathrm{C}$ values of the two alkane gases (Table 3, Fig. 6a, b, c and d). Because some of the alkane gas $\delta^{13} \mathrm{C}$ values were not determined, only nine gases of the $\mathrm{E}_{3} \mathrm{~d}$ reservoirs in the $\mathrm{ED}$ have the carbon isotopic values from methane to butane $\left(\delta^{13} \mathrm{C}_{1-4}\right)$, and seven of them have the carbon isotope reversal exhibiting a reversal ratio of $77.8 \%$ (reversal ratio=number of the gas samples with reversed isotopes/ total gas numbers of the same strata $\times 100 \%)$. The reversal ratios of the $\mathrm{E}_{3} \mathrm{~s}^{1}$ reservoirs in the ED and WD are $63.6 \%$ and $57.1 \%$, respectively. The reservoirs with smaller burial depths have greater carbon isotope reversal ratios, whereas deeply buried reservoirs exhibit lower reversal ratios. For example, 
the ratios of the $\mathrm{E}_{2} \mathrm{~s}^{3}$ gases in the ED and WD are only $25 \%$ and $44.4 \%$, respectively. The reversal ratios of the gases in $\mathrm{E}_{3} \mathrm{~d}$ and $\mathrm{E}_{3} \mathrm{~s}^{1}$ in the $\mathrm{ED}$ are higher than those in the $\mathrm{WD}$, while the reversal ratios of the gases in the $\mathrm{E}_{2} \mathrm{~s}^{3}$ exhibit the opposite trend. The extent of reversal between the $\delta^{13} \mathrm{C}_{3}$ and $\delta^{13} \mathrm{C}_{4}$ values of the gases in the $\mathrm{E}_{3} \mathrm{~s}^{1}$ and $\mathrm{E}_{2} \mathrm{~s}^{3}$ reservoirs in the WD increases with decreasing depth (Fig. 6a and b); The extent of reversal between the ${ }^{13} \mathrm{C}_{3}$ and ${ }^{13} \mathrm{C}_{4}$ values of the gases in the Ed Fm. is larger than the ones in the $\mathrm{E}_{3} \mathrm{~s}^{1}$ and $\mathrm{E}_{2} \mathrm{~s}^{3}$ reservoirs in the $\mathrm{ED}$ (Fig. 6c, $\mathrm{d}$ and e).

Variable $\delta^{13} \mathrm{C}_{\mathrm{CO} 2}$ values are found in the gases of different Paleogene reservoirs in the Liaohe Basin (Tables 3 and 4). Generally, the $\delta^{13} \mathrm{C}_{\mathrm{CO} 2}$ values of the gases in the ED are much more negative than those in the $\mathrm{WD}$, and the variations in $\delta^{13} \mathrm{C}_{\mathrm{CO} 2}$ are less obvious in the $\mathrm{ED}$ than in the WD.

\subsubsection{Hydrogen isotopes of the alkane gases}

The differences of the $\delta^{2} \mathrm{H}$ values of methane among the $\mathrm{E}_{3} \mathrm{~s}^{1}$ and $\mathrm{E}_{2} \mathrm{~s}^{3}$ reservoirs of the WD are not obvious, whereas the differences in the $\delta^{2} \mathrm{H}$ values of ethane and propane of different gases reservoired in the $\mathrm{E}_{3} \mathrm{~s}^{1}$ and $\mathrm{E}_{2} \mathrm{~s}^{3}$ are much more apparent (Tables 3 and 4; Fig. 7a and b). The trends of the curves for the hydrogen isotope values of methane and its homologues in the $\mathrm{E}_{3} \mathrm{~s}^{1}$ reservoirs are similar, whereas those of the $\mathrm{E}_{2} \mathrm{~s}^{3}$ reservoirs display two obviously different styles (Fig. 7a and b).

The $\delta^{2} \mathrm{H}$ values of the methane and ethane of the $\mathrm{E}_{3} \mathrm{~d}$ reservoirs in the ED are distributed in a narrow range excepting the gas in well R161-25 of Rongxingtun oil and gas field, whereas those of propane are distribute widely (Fig. 7c). The curve styles for the hydrogen isotope values of methane and its homologues in the $\mathrm{E}_{3} \mathrm{~d}$ reservoirs in the $\mathrm{ED}$ are similar (Fig. 7c), and the hydrogen isotope values of the alkane gases in the $\mathrm{E}_{3} \mathrm{~s}^{1}$ and $\mathrm{E}_{2} \mathrm{~s}^{3}$ reservoirs both exhibit wide distributions (Fig. 7d).

The $\delta^{2} \mathrm{H}$ values of the alkane gases in the $\mathrm{E}_{3} \mathrm{~s}^{1}$ and $\mathrm{E}_{2} \mathrm{~s}^{3}$ reservoirs in the WD decrease with increasing depth (Figs. 8a, b and c). The $\delta^{2} \mathrm{H}_{\mathrm{CH} 4}$ values in the $\mathrm{E}_{3} \mathrm{~s}^{1}$ and $\mathrm{E}_{3} \mathrm{~d}$ reservoirs in the ED increase with increasing depth, whereas those of methane in the $\mathrm{E}_{2} \mathrm{~s}^{3}$ reservoirs show no clear correlation with depth (Fig. 8a). The $\delta^{2} \mathrm{H}_{\mathrm{C} 2 \mathrm{H} 6}$ values in the $\mathrm{E}_{3} \mathrm{~d}, \mathrm{E}_{3} \mathrm{~s}^{1}$ and $\mathrm{E}_{2} \mathrm{~s}^{3}$ reservoirs of the ED all decrease with increasing depth, although a few values in the $\mathrm{E}_{3} \mathrm{~s}^{1}$ do not follow this trend (Fig. $8 b$ ). No obvious correlation between the $\delta^{2} \mathrm{H}_{\mathrm{C} 3 \mathrm{H} 8}$ values with depth is observed in the ED (Fig. 
$8 c)$.

\section{Discussion}

\subsection{Genetic types of the natural gases}

Chung et al. (1988) suggested that in an unaltered gas, co-generated components will exhibit linearity in the isotope type curve (Fig. 6). The isotope type curves of the gases in the $\mathrm{E}_{3} \mathrm{~s}^{1}$ and $\mathrm{E}_{2} \mathrm{~s}^{3}$ reservoirs in the WD and in the $\mathrm{E}_{3} \mathrm{~d}$ and $\mathrm{E}_{3} \mathrm{~s}^{1}$ reservoirs in the ED do not display linearity, indicating that these gases are mixtures of gases of different genetic types or result from alteration within the reservoir. The Paleogene gases of the Liaohe Basin are all organic gases, and most are thermogenic (Figs. 9 and 10). A few of the gases in the $\mathrm{E}_{3} \mathrm{~s}^{1}$ reservoirs are mixtures of microbial and thermogenic gases, as shown in Fig. 9. Fig.10 displays the genetic types of the gases of the basin, and the identification results of the gas types made by it are very similar to the ones made using Fig. 9, except that some gases in the $\mathrm{E}_{2} \mathrm{~s}^{3}$ reservoirs in the WD experienced a little mixing with microbial gas. Gases reservoired in the $\mathrm{E}_{2} \mathrm{~s}^{3}$ and $\mathrm{E}_{3} \mathrm{~s}^{1}$ strata in WD with $\delta^{13} \mathrm{C}_{\mathrm{CO} 2}>+2 \%$, and isotopically light methane $\left(\delta^{13} \mathrm{C}_{1}<-50 \%\right.$ ) (Fig. 10) indicate that the methanes are of secondary microbial methane which were generated from $\mathrm{CO}_{2}$ reduction under anaerobic conditions.

The $\delta^{13} \mathrm{C}$ value of ethane is commonly used to differentiate humic gas from sapropelic gas, with the empirical value of $-28 \%$ usually being the distinguishing value $\left(\delta^{13} \mathrm{C}_{2}<-28 \%\right.$ indicates sapropelic gas, and $\delta^{13} \mathrm{C}_{2}>-28 \%$ indicates humic gas) (Dai et al., 1992; Dai., 2011; Liang et al., 2002; Liu et al., 2008, 2011; Xu and Shen, 1996). The $\delta^{13} \mathrm{C}$ values of ethane in the WD are generally less than $-28 \%$ (Fig. 5c, Fig. 6a and b), indicating that the majority of these gases are sapropelic gases. The $\delta^{13} \mathrm{C}$ values of ethane in the $\mathrm{E}_{3} \mathrm{~d}$ reservoirs of $\mathrm{ED}$ are mainly greater than $-28 \%$ (Fig. $5 \mathrm{c}$ and Fig. 6c), suggesting that these are mainly humic gases. Some of $\delta^{13} \mathrm{C}_{2}$ values of the gases in the $\mathrm{E}_{3} \mathrm{~s}^{1}$ and $\mathrm{E}_{2} \mathrm{~s}^{3}$ reservoirs of $\mathrm{ED}$ are less than $-28 \%$, while some are greater than $-28 \%$, indicating that both sapropelic and humic gases are present in these two reservoirs. The $\delta^{13} \mathrm{C}_{2}$ value of the gases in the KH8 well of the $\mathrm{E}_{3} \mathrm{~d}$ reservoir in the offshore Kuihuadao oil field is $-26.6 \%$, indicating typical humic gases.

$\delta^{13} \mathrm{C}_{1}$ versus $\delta^{13} \mathrm{C}_{2}$ diagrams are often used to identify gas types of different origins (Fig. 11) (Jenden et al., 1988; Dai and Qi., 1989; Rooney et al., 1995; Berner and Faber., 1996; Tilley and Muehlenbachs, 2006). The gases in the $\mathrm{E}_{3} \mathrm{~d}$ reservoirs in the ED distribute along the trend of gases generated by type III kerogen, indicating that the gases are mainly humic gases. The gases of other 
reservoirs are widely distributed; some of them distribute along the trend of type III kerogen, while others distribute along the trend of type II kerogen (Fig. 11), suggesting that both sapropelic and humic gases are present in these reservoirs. The $\delta^{13} \mathrm{C}_{2}$ values in the WD are generally more negative than those in the ED, indicating that the gases of the two depressions have different sources; the gases of the WD were generated by source rocks with much more negative carbon isotope values, which is of type I-II probably.

The $\delta^{13} \mathrm{C}_{1}$ versus $\mathrm{C}_{1} / \mathrm{C}_{2+3}$ diagram can also identify microbial gas and mixed gas (Fig. 12) (Whiticar, 1999). Fig. 12 indicates that the gases of the $\mathrm{E}_{2} \mathrm{~s}^{3}$ and $\mathrm{E}_{2} \mathrm{~s}^{4}$ reservoirs in the Lengjiapu oil field in the WD mainly distribute along the trend of type II kerogen, suggesting that the gases are mainly sapropelic ones. The gas in the X10 well of the $\mathrm{E}_{2} \mathrm{~s}^{3}$ reservoir in the Yulou oil and gas field (ED) is mainly microbial gas with very negative $\delta^{13} \mathrm{C}_{1}$ values. The gases in the $\mathrm{E}_{3} \mathrm{~d}$ reservoirs in the ED are mainly humic gases with a few sapropelic gases. Many of the gases in the $\mathrm{E}_{3} \mathrm{~s}^{1}$ reservoirs of the entire basin and the $\mathrm{E}_{2} \mathrm{~s}^{3}$ reservoirs of the $\mathrm{ED}$ are mixtures of thermogenic and microbial gases, and the mixing ratios of the gases in the $\mathrm{E}_{3} \mathrm{~s}^{1}$ reservoirs are much greater than those of the $\mathrm{E}_{2} \mathrm{~s}^{3}$ gases. The sapropelic gases of the $\mathrm{E}_{3} \mathrm{~s}^{1}$ reservoirs in the $\mathrm{ED}$ are mainly distributed in the Rehetai and Qinglongtai oil and gas fields, whereas the humic gases of the $\mathrm{E}_{2} \mathrm{~s}^{3}$ reservoirs (ED) are mainly distributed in the Dapingfang and Yushutai oil and gas fields; the gases of the $\mathrm{E}_{2} \mathrm{~s}^{3}$ reservoirs of other fields in the ED are mainly sapropelic gases (Table 2, Table 3 and Fig. 12).

\subsection{Mixing ratios of microbial and thermogenic gases}

Microbial gases are characterised by depleted methane $\delta^{13} \mathrm{C}$ values $(-60 \% \sim-100 \%)$ (Schoell, 1980; Whichar, 1999; Valentine et al., 2004). The methane $\delta^{13} \mathrm{C}$ values of thermogenic gas in the Liaohe Basin are approximately $-40 \%$ (Figs. $5 \mathrm{a}$ and 11 ); thus, $-60 \%$ and $-40 \%$ were chosen as the $\delta^{13} \mathrm{C}$ values of microbial and thermogenic gases, respectively, to estimate the mixing ratio.

The methane $\delta^{13} \mathrm{C}$ values of the gas in the $\mathrm{E}_{3} \mathrm{~s}^{1}$ reservoirs range from $-50.5 \%$ to $-55.4 \%$ in the Lengiiapu oil field in the WD, and the microbial gas accounts for $50 \%$ to $75 \%$ of the whole gas. The contributions of microbial gas are all below $15 \%$ in the other gases in the $\mathrm{E}_{3} \mathrm{~s}^{1}$ reservoirs of the field.

The methane $\delta^{13} \mathrm{C}$ values of the $\mathrm{E}_{3} \mathrm{~s}^{1}$ reservoir in the Qinglongtai oil and gas field (ED) range 
from $-52.0 \%$ to $-55.5 \%$, and the microbial gas ratios are $60 \%$ to $75 \%$. The percentage contribution of microbial gas to total volume in the $\mathrm{Y} 9$ well from the $\mathrm{E}_{3} \mathrm{~s}^{1}$ reservoir in the Yulou oil and gas field reaches $60 \%$. The methane $\delta^{13} \mathrm{C}$ values of the $\mathrm{L} 12$ well in the $\mathrm{E}_{3} \mathrm{~s}^{1}$ reservoir of the Oulituozi field is $-60.1 \%$, and the gas is typical microbial gas. Methane $\delta^{13} \mathrm{C}$ values of the gas in the $\mathrm{E}_{3} \mathrm{~s}^{1}$ reservoir of well RQ2 and R44, Rehetai field are $-49.4 \%$ and $-53.5 \%$, and the contribution of the microbial gas are approximately $45 \%$, and $65 \%$, respectively. Except the above-mentioned gases, the contributions of microbial gas to the gases of other wells in the $\mathrm{E}_{3} \mathrm{~s}^{1}$ reservoir in the ED are very low $(<15 \%)$, and most of the gases are purely thermogenic.

A few gases in the $\mathrm{E}_{2} \mathrm{~s}^{3}$ reservoirs of the $\mathrm{ED}$ have some microbial gas contribution, including gases in the R20-11 well in the Rehetai field, the L26-20 and L25-16 wells in the Qinglongtai field; the methane $\delta^{13} \mathrm{C}$ values of these three wells are $-49.6 \%,-47.9 \%$, and $-50.6 \%$, respectively, and the corresponding contributions of microbial gas to these four gases are $50 \%$, $40 \%$ and $55 \%$, respectively. The gas reservoired in the $\mathrm{E}_{2} \mathrm{~s}^{3}$ of the X10 well in the Yulou field has a methane $\delta^{13} \mathrm{C}$ value of $-59.3 \%$, and the contribution of the microbial gas is more than $95 \%$ (Fig.12).

\subsection{Effects of biodegradation}

The effects of biodegradation on the carbon isotopic compositions of gases have been comprehensively studied. The preferential removal of isotopically light components is known to result in somewhat higher $\delta^{13} \mathrm{C}$ values in the residual gas (Fuex, 1977; Coleman and Risatti., 1981; Rice and Claypool, 1981; Katz et al., 2002; Dai et al., 2004). Among the wet gases, ethane is more resistive to biodegradation compared to other gases, and propane is typically the first gas to undergo biodegradation, likely because propane is the first and most water-soluble $n$-alkane to have a secondary carbon, which is the position that is primarily attacked in anaerobic alkane activation during biodegradation (Fuex, 1977; James and Burns, 1984; Xu et al., 1997; Head et al., 2003; Dai et al., 2004; Larter et al., 2005). The $\delta^{13} \mathrm{C}_{3}$ values are greater than the $\delta^{13} \mathrm{C}_{4}$ values for some of the gases in the $\mathrm{E}_{3} \mathrm{~s}^{1}$ and $\mathrm{E}_{2} \mathrm{~s}^{3}$ reservoirs of the Lengjiapu oil field in the WD (Fig. 6a, 6b and 13) and in the $\mathrm{E}_{3} \mathrm{~d}$ and $\mathrm{E}_{3} \mathrm{~s}^{1}$ reservoirs in the ED (Figs. 6c, 6d and 13), indicating that these gases underwent biodegradation. The extent of the reversal of carbon isotopes in the gases of the $\mathrm{E}_{2} \mathrm{~s}^{3}$ reservoir (ED) is lower than that of the $\mathrm{E}_{3} \mathrm{~d}$ gases (Fig. 6e), suggesting that the $\mathrm{E}_{2} \mathrm{~s}^{3}$ gases experienced less biodegradation than the $\mathrm{E}_{2} \mathrm{~d}$ gases. Normal alkanes are more susceptible to 
biodegradation than the corresponding iso-alkanes, and the $i \mathrm{C}_{4} / n \mathrm{C}_{4}$ ratio, which is a good indicator of gas biodegradation, increases significantly with increasing extent of biodegradation (James and Burns, 1984; Horstad and Larter, 1997; Pallasser, 2000; Larter and di Primio, 2005). The $i \mathrm{C}_{4} / n \mathrm{C}_{4}$ ratio for non-degraded gas samples is typically $<0.8$, while the ratio for biodegraded samples can be up to 1.75; furthermore, a positive correlation between the $\mathrm{C}_{2} / \mathrm{C}_{3}$ and $i \mathrm{C}_{4} / n \mathrm{C}_{4}$ ratios can indicate biodegradation (Huang et al., 2004). The gases in the $\mathrm{E}_{3} \mathrm{~d}$ reservoirs in the ED experienced intense biodegradation $\left(0.75<i \mathrm{C}_{4} / n \mathrm{C}_{4}>2.75, \mathrm{C}_{2} / \mathrm{C}_{3}>1.0\right)$, while the gases of the $\mathrm{E}_{3} \mathrm{~s}^{1}$ reservoirs in the WD experienced weaker biodegradation $\left(0.55<i \mathrm{C}_{4} / n \mathrm{C}_{4}>1.67,0.26<\right.$ $\mathrm{C}_{2} / \mathrm{C}_{3}<2.33$ ). The extent of biodegradation was lowest for the gases in the $\mathrm{E}_{3} \mathrm{~s}^{1}$ and $\mathrm{E}_{2} \mathrm{~s}^{3}$ reservoirs in the ED (Fig. 14). The $i \mathrm{C}_{4} / n \mathrm{C}_{4}$ values should increase with increasing thermal maturity (Durand and Espitalié, 1972; Hunt, 1984). Because the gases in the $\mathrm{E}_{3} \mathrm{~s}^{1}$ and $\mathrm{E}_{2} \mathrm{~s}^{3}$ reservoirs are buried much deeper than the ones of the $\mathrm{E}_{3} \mathrm{~d}$, and consequently the $i \mathrm{C}_{4} / n \mathrm{C}_{4}$ values of the $E_{3} s^{1}$ and $E_{2} s^{3}$ reservoirs would be much greater than the ones of $E_{3} d$ in usual. However, the fact is that the $i \mathrm{C}_{4} / n \mathrm{C}_{4}$ values of the $\mathrm{E}_{3} \mathrm{~s}^{1}$ and $\mathrm{E}_{2} \mathrm{~s}^{3}$ are much less than the ones in the $\mathrm{E}_{3} \mathrm{~d}$, indicating the gases in the latter reservoirs of the ED experienced intense biodegradation.

The reversal of carbon isotope values in alkane gases may be caused by (1) mixing of biogenic and abiogenic gas; (2) mixing of a humic gas with a sapropelic gas; (3) mixing of gases of the same type from different sources, or gases from the same source generated in different episodes (Berner and Faber, 1988; James, 1990; Dai et al., 2004); (4) biodegradation of certain gas components (James and Burns, 1984; Dai et al., 2004). The reversal of the carbon isotopic trends of the alkane gases $\left(\delta^{13} \mathrm{C}_{1}<\delta^{13} \mathrm{C}_{2}<\delta^{13} \mathrm{C}_{3}>\delta^{13} \mathrm{C}_{4}\right)$ in the Liaohe Basin is mainly caused by the biodegradation of propane. Since multiple gas types are found in the basin, the mixing of different kinds of thermogenic gases causing the reversion of carbon isotopic composition cannot be excluded.

\subsection{Thermal maturity}

The $\delta^{13} \mathrm{C}$ values of alkane gas increase with increasing thermal maturity (vitrinite reflectance, $\mathrm{VR}_{\mathrm{o}}$ ), and many relationships have been proposed in past reports (Stahl and Carey, 1975; Stahl, 1977; Schoell, 1983; Berner and Faber, 1988; Dai and Qi, 1989). The mixing of the microbial and thermogenic gases would cause the methane $\delta^{13} \mathrm{C}$ value to be much more negative; consequently, the value of $\mathrm{R}_{\mathrm{o}}$ estimated using the $\delta^{13} \mathrm{C}-\mathrm{VR}_{\mathrm{o}}$ relationship would be unrealistic (Katz et al., 2002; 
Martini et al., 2008; Faber et al., 2015). Faber et al (2015) proposed using the bulk carbon isotopic compositions of the methane, ethane, and propane with different kerogen types to estimate the maturity at time of formation of the gas, and this method is used in this work (Fig. 15).

As discussed above, gases produced from the $\mathrm{E}_{3} \mathrm{~s}^{1}$ reservoir in some wells of Qinglongtai field (well LQ4, LQ5, L9, L14-21, and L 20-21), Yulou Field (well Y9), Oulituozi field (well L12), Huangjindai field (H34), and Rehetai filed (well R44 and RQ2), and the gases of $\mathrm{E}_{2} \mathrm{~s}^{3}$ reservoir in Rehetai field (well R22-11), and Qinglongtai field (well L25-16 and L26-20) in ED are mixtures of microbial gas and thermogenic gas. Thus, these gases have to be excluded from the maturity evaluation.

Gases in the $\mathrm{E}_{2} \mathrm{~s}^{3}$ reservoirs of well O6, O13 of Oulituozi field and well $\mathrm{H} 202$ of Huangjindai field of ED are oil associated gases, and the $\mathrm{VR}_{\mathrm{o}}$ values of them are about $1.3 \% \sim 1.5 \%$ (Fig. 15), indicating they were generated by the mature to highly mature sapropelic source rocks. The gas in the $\mathrm{E}_{3} \mathrm{~s}^{1}$ of well Y4-2 of Yulou field of ED is oil associated, with a $\mathrm{VR}_{\mathrm{o}}$ value of $1.2 \%$. Excepting the gases produced from the previous four wells, the ones reservoired in the $E_{3} d, E_{3} s^{1}$ and $E_{2} s^{3}$ reservoirs of ED are mainly of humic gas type, most of whose $\mathrm{VR}_{\mathrm{o}}$ values are less than $1.0 \%$ (Fig. 15), indicating they were generated in the early mature to mature stage by humic source rocks.

Gases reservoired in the $\mathrm{E}_{3} \mathrm{~s}^{1}$ and $\mathrm{E}_{2} \mathrm{~s}^{3}$ formations of Lengiapu oil field of WD are mainly oil associated gases except for a few that are mixed with microbial gas in $\mathrm{E}_{3} \mathrm{~S}^{1}$. The $\mathrm{VR}_{\mathrm{o}}$ values of the sapropelic gases in the $\mathrm{E}_{3} \mathrm{~s}^{1}$ reservoir of Lengjiapu oil field are from $1.3 \%$ to $1.7 \%$ (Fig. 15), while the ones in the $\mathrm{E}_{2} \mathrm{~s}^{3}$ reservoir are from $0.7 \%$ to $1.2 \%\left(\mathrm{VR}_{\mathrm{o}}\right.$; Fig. 15). The gas produced from the $\mathrm{E}_{2} \mathrm{~s}^{4}$ reservoir of the well Q4 in Qijia field of WD has a $\mathrm{VR}_{\mathrm{o}}$ value of about $1.3 \%$.

\subsection{Gas-source correlation}

Since the Liaohe basin is a rift basin with well-developed faults vertically connecting different source rock strata (Fig. 3), hydrocarbons generated by different source rocks could mixed together in the same reservoir (Zhang et al., 1995; Chen et al., 1998; Koopmans et al., 2002). In this work, only molecular and isotopic compositions of the gases combined with thermal history of the potential source rocks are used to identify the gas-source correlations. Much additional work is needed to evaluate correlation possibilities in full.

As discussed above, the thermogenic gases in the $\mathrm{E}_{3} \mathrm{~s}^{1}$ and $\mathrm{E}_{2} \mathrm{~s}^{4}$ of WD were generated by highly mature source rocks. Most of the source rocks of $\mathrm{E}_{2} \mathrm{~s}^{4}$ of WD are highly mature to over 
mature at present (Zhang et al., 2002; Hu et al., 2005) and the gases in the $\mathrm{E}_{3} \mathrm{~s}^{1}$ and $\mathrm{E}_{2} \mathrm{~s}^{4}$ of WD would probably be derived from the $\mathrm{E}_{2} \mathrm{~s}^{4}$ sapropelic source rocks. Because part of the $\mathrm{E}_{2} \mathrm{~s}^{3}$ source rocks of WD are highly mature at present, its contribution to the gas accumulation of the $\mathrm{E}_{3} \mathrm{~s}^{1}$ reservoir cannot be excluded. Thermogenic gases reservoired in $\mathrm{E}_{2} \mathrm{~s}^{3}$ of WD were generated by mature source rocks. This is consistent with the thermal maturity of the $\mathrm{E}_{2} \mathrm{~s}^{3}$ source rocks $(0.5 \%<$ $\mathrm{VR}_{\mathrm{o}}<1.3 \%$, Table 1 ), so the gases were probably generated by the $\mathrm{E}_{2} \mathrm{~s}^{3}$ source rocks.

The sapropelic gases reservoired in the $\mathrm{E}_{2} \mathrm{~s}^{3}$ and $\mathrm{E}_{3} \mathrm{~s}^{1}$ strata of ED were derived in the highly mature stage, which is coincident with the thermal maturity of the $\mathrm{E}_{2} \mathrm{~s}^{3}$ source rocks $\left(0.7 \%<\mathrm{VR}_{\mathrm{o}}\right.$ $<1.3 \%$, Table 1), and the gases were probably generated by the $\mathrm{E}_{2} \mathrm{~s}^{3}$ source rock strata. The origins of the remaining thermogenic gases of ED are not easy to determine because the $\mathrm{E}_{2} \mathrm{~s}^{3}$ and $\mathrm{E}_{3} \mathrm{~S}^{1-2}$ source rocks could both generate early mature gases, and the gases generated by the two source rocks could migrated along the faults and accumulate together in the same reservoir, so both of these two source rocks strata could contribute to the gas reservoirs.

Gases with $\delta^{13} \mathrm{C}_{\mathrm{CO} 2}>+2 \%$ and isotopically light methane $\left(\delta^{13} \mathrm{C}_{1}<-50 \%\right.$ ) were generated from $\mathrm{CO}_{2}$ reduction under anaerobic conditions (Huang et al., 2014), while the ones with negative $\delta^{13} \mathrm{C}_{\mathrm{CO} 2}$ isotopes and isotopically light methane $\left(\delta^{13} \mathrm{C}_{1}<-50 \%\right)$ were probably generated by acetate-type fermentation. Most of the reservoir depths of the gases with microbial gas mixed are less than $1800 \mathrm{~m}$ (Table 2), and these reservoir temperatures are less than $80{ }^{\circ} \mathrm{C}$. Under such condition, the microbial methane would be formed when the organic matter experienced acetate fermentation (Whiticar, 1999). The source rocks might be very close to the reservoirs making the microbial gas migrate and accumulate easily.

\section{Conclusions}

Using the analysis of the molecular and isotopic $(\mathrm{C}$ and $\mathrm{H})$ compositions of the Paleogene natural gases as well as the source rock characteristics of the Liaohe Basin, the genetic origins, maturities, secondary alteration and gas-source correlations of the gases were studied. The main conclusions are listed below.

a. The natural gases of the Liaohe Basin are mainly wet gases, with the exceptions of the dry ones in the $\mathrm{E}_{2} \mathrm{~S}^{3}$ reservoirs of the ED. Methane is the dominant alkane component. Nitrogen and carbon dioxide are the two main non-hydrocarbons, and the contents of both are generally less than $5 \%$. 
b. The carbon and hydrogen isotopic values of the alkane gases have wide distributions, and except for the ones of the $\delta^{13} \mathrm{C}_{2}$ values of the $\mathrm{ED}$, the isotopic values of other alkane components do not display clear correlations with depth due to the influences of maturity, migration and mixing.

c. Multiple genetic gas types are found in the basin, including thermogenic gas (sapropelic gas, humic gas), microbial gas and mixed gas. The gases in the $\mathrm{E}_{2} \mathrm{~s}^{3}$ and $\mathrm{E}_{2} \mathrm{~s}^{4}$ reservoirs in the Lengjiapu oil field are mainly sapropelic gases, whereas the gas in the L12 well $\left(\mathrm{E}_{3} \mathrm{~s}^{1}\right.$ reservoir) of Oulituozi field and the well X10 ( $\mathrm{E}_{2} \mathrm{~s}^{3}$ reservoir) of the Yulou field in the ED are microbial. The gases in the $\mathrm{E}_{3} \mathrm{~s}^{1}$ reservoir in the WD and the $\mathrm{E}_{2} \mathrm{~s}^{3}$ reservoirs in the ED are of multiple genetic types, and a mixture of thermogenic and microbial is observed. Microbial gas accounts for $50 \%$ to $75 \%$ of the mixed gases in the $\mathrm{E}_{3} \mathrm{~s}^{1}$ reservoirs in the WD, while it accounts for $40 \%$ to $75 \%$ of the mixed gases in the $\mathrm{E}_{3} \mathrm{~s}^{1}$ reservoirs in the $\mathrm{ED}$.

d. The natural gases in the $\mathrm{E}_{3} \mathrm{~d}$ reservoirs of the ED experienced substantial biodegradation, much more extensive than in the $\mathrm{E}_{3} \mathrm{~s}^{1}$ reservoirs of the WD and in the $\mathrm{E}_{3} \mathrm{~s}^{1}$ and $\mathrm{E}_{2} \mathrm{~s}^{3}$ reservoirs in the ED. A reversal of the carbon isotopic trends $\left(\delta^{13} \mathrm{C}_{1}<\delta^{13} \mathrm{C}_{2}<\delta^{13} \mathrm{C}_{3}>\delta^{13} \mathrm{C}_{4}\right)$ can be found in different reservoirs of the basin and is mainly caused by the biodegradation of propane. The reversed trends in the shallow reservoirs $\left(\mathrm{E}_{3} \mathrm{~d}\right.$ and $\left.\mathrm{E}_{3} \mathrm{~s}^{1}\right)$ are greater than in the deep ones $\left(\mathrm{E}_{2} \mathrm{~s}^{3}\right)$.

e. The humic natural gases of the ED were mainly generated by source rocks at the early mature stage, while the sapropelic ones of the ED and WD were generated during the mature to highly mature stages.

f. Both $\mathrm{E}_{2} \mathrm{~s}^{3}$ and $\mathrm{E}_{2} \mathrm{~s}^{4}$ source rocks could contribute to the gas reservoirs of $\mathrm{E}_{2} \mathrm{~s}^{3}$ and $\mathrm{E}_{3} \mathrm{~s}^{1}$ in the WD; sapropelic gases in ED were generated by $\mathrm{E}_{2} \mathrm{~s}^{3}$ source rocks, while the other gases reservoired in the $E_{2} s^{3}, E_{3} s^{1}$, and $E_{3} d$ strata of $E D$ are probably sourced from $E_{2} s^{3}$ and $E_{3} s^{1-2}$.

\section{Acknowledgement}

This work was financially supported by the PetroChina Petroleum Exploration Major Science and Technology Program "Geochemistry and accumulation mechanisms of coal-formed gas in China" (No. 2014B-0608), and the National Science Foundation Project for Young Scholars of China (No. 41303037). We would like to acknowledge Professor Jinxing Dai from RIPED, PetroChina, for his critical and constructive comments. Four anonymous reviewers and Professor Shifeng Dai are gratefully acknowledged for their constructive comments that substantially 
improved the quality of this manuscript.

\section{References}

Berner, U., Faber, E., 1988. Maturity related mixing model for methane, ethane and propane, based on carbon isotopes. Organic Geochemistry. 13 (1-13), 67-72.

Berner, U., Faber, E., 1996. Empirical carbon isotope/maturity relationships for gases from algal kerogens and terrigenous organic matter, based on dry, open-system pyrolysis. Organic Geochemistry 24, 947-955.

Chen, J.F., Chen, Z.Y., Ji, D.M., Yu, S., Zhao, C.H., Wang, X.B., 1998. Genetic origin of the intensely larger isotope values of the ethane and propane of natural gases from Liaohe Basin. Acta Sedimentologica Sinica 16(2), 5-8 (in Chinese with English abstract)

Chung, H.M., Gormly, J.R., Squires, R.M., 1988. Origin of gaseous hydrocarbons in subsurface environments: Theoretical considerations of carbon isotope distribution. Chemical Geology 71, 97-103.

Coleman, D.D., Risatti, J.B., 1981. Fractionation of carbon and hydrogen isotopes by methane-oxidizing bacteria. Geochimica et Cosmochimica Acta 45, 1033-1037.

Collett, T.S., 2002. Energy resource potential of natural gas hydrates. American Association of Petroleum Geologists Bulletin 86 (11), 1971-1992.

Dai J.X., 2011. Significances of the study on carbon isotopes of alkane gases. Natural Gas Industry 31 (2), 1-6 (in Chinese with English abstract).

Dai, J.X., Qi, H.F., 1989. Relationship of $\delta^{13} \mathrm{C}-\mathrm{R}_{\mathrm{o}}$ of coal-formed gas in China. Chinese Science Bulletin 34, 690-692 (in Chinese with English abstract).

Dai, J.X., Pei, X.G., Qi, H.F., 1992. China Natural Gas Geology (Vol.1). Beijing, Petroleum Industry Press, p. 35-86 (in Chinese).

Dai, J.X., Xia, X.Y., Qin, S.F., Zhao, J.Z., 2004. Origins of partially reversed alkane $\delta^{13} \mathrm{C}$ values for biogenic gases in China. Organic Geochemistry 35, 405-411.

Dai, J,X., Xia, X.Y., Li, Z.S., Coleman, D.D., Dias, R.F., Gao, L., Li, J., Deev, A., Li, J., Dessort, D., Dulerc, D., Li, L.W., Liu, J.Z., Schloemer, S., Zhang, W.L., Ni, Y.Y., Hu, G.Y., Wang, X.B., Tang, Y.C., 2012. Inter-laboratory calibration of natural gas round robins for $\delta^{2} \mathrm{H}$ and $\delta^{13} \mathrm{C}$ using off-line and on-line techniques. Chemical Geology, 310-311: 49-55.

Durand, B., Espitalié, J., 1972. Formation and evolution of hydrocarbons from $C_{1}$ to $C_{15}$ and permanent gases in the Toarcien clays of the Paris basin.In: Von Gaertner, H.R., Wehner, H. (Eds.), Advances in Organic 
Geochemistry, 1971, Proceedings of the 5th International Meeting on Organic Geochemistry, Hannover, $7 \mathrm{u}$ Toarcien of the Paris Basin. Iess, Oxford, Braunschweig, pp. 455-488.

Faber, E., 1995. Origin of hydrocarbon gases in the pump-test of the KTB pilot well. Scientific Drilling 5, pp. 123-128.

Faber, E., Schmidt. M., Feyzullayev, A.A., 2015. Geochemical hydrocarbon exploration-insights from stable isotope models. Oil and Gas European Magazine, 2015,2, 93-98.

Fuex, A.N., 1977. The use of stable carbon isotopes in hydrocarbon exploration. Journal of Geochemical Exploration 7,155-188.

Fuhrmann, A., Horsfield, B., Lòpez, J.F., Hu, L.G., Zhang, Z.W., 2004. Organic facies, depositional environment and petroleum generation characteristics of the lacustrine Shahejie Formation, Es4 member, Western Depression, Liaohe Basin (NE China). Journal of Petroleum Geology 27(1), 27-46.

Galimov, E.M., 2006. Isotope organic geochemistry. Organic Geochemistry 37, 1200-1262.

$\mathrm{Gu}, \mathrm{T}$., 2016. The theory of source-oriented fine exploration of hydrocarbon-rich depression and its application. Beijing, Science Press, p. 31-44, 173-183.

Gutsalo, L.K., Plotnikov, A.M., 1981. Carbon isotopic composition in the $\mathrm{CH}_{4}-\mathrm{CO}_{2}$ system as a criterion for the origin of methane and carbon dioxide in Earth natural gases. Dokl. Akad. Nauk. SSSR 259, 470-473 (in Russian).

Hao, F., Guo, T.L., Zhu, Y.M., Cai, X.Y., Zou, H.Y., Li, P.P., 2008. Evidence for multiple stages of oil cracking and thermochemical sulfate reduction in the Puguang gas field, Sichuan Basin, China. American Association of Petroleum Geologists Bulletin 92 (5), 611-637.

Head, I.M., Jones, D.M., Larter, S.R., 2003. Biological activity in the deep subsurface and the origin of heavy oil. Nature 426, 344-353.

Horstad, I., Larter, S.R., 1997. Petroleum migration, alteration, and remigration within Troll Field, Norwegian North Sea. American Association of Petroleum Geologists Bulletin 81, 222-248.

Hu, L.G., Fuhrmann, A. Poelchau, H.S., Horsfield, B., Zhang, Z.W., Wu, T.S., Chen, Y.X., Li, J.Y., 2005. Numerical simulation of petroleum generation and migration in the Qingshui sag, western depression of the Liaohe basin, northeast China. American Association of Petroleum Geologists Bulletin 89(12), 1629-1649.

Huang, H.P., Bowler, B.F., Oldenburg, T.B.P., Larter, S. R., 2004. The effect of biodegradation on polycyclic aromatic hydrocarbons in reservoired oils from the Liaohe basin, NE China. Organic Geochemistry 35, $1619-1634$. 
Huang, H.P., \& Larter, S., 2014. Secondary microbial gas formation associated with biodegraded oils from the Liaohe Basin, NE China. Organic Geochemistry 68, 39-50.

Hunt, J.M., 1984. Generation and migration of light hydrocarbons. Science 226, 1265-1270.

James, A. T., \& Burns, B. J.,1984. Microbial alteration of subsurface natural gas accumulations. American Association of Petroleum Geologists Bulletin, 68, 957-960.

James, A.T., 1990. Correlation of reservoired gases using the carbon isotopic composition of wet gas components. American Association of Petroleum Geologists Bulletin 74, 1141-1158.

Jenden P. D., Kaplan, I. R., Poreda, R., Craig, H., 1988. Origin of nitrogen-rich natural gases in the California Great Valley: Evidence from helium, carbon and nitrogen isotopic ratios. Geochimica et Cosmochimica Acta 52 (4), 851-861.

Katz, B.J., Narimanov, A., Huseinzadeh, R., 2002. Significance of microbial processes in gases of the South Caspian basin. Marine and Petroleum Geology 19, 783-796.

Koopmans, M.P., Larter, S., Zhang, C.M., Mei, B.W., Wu, T.S., Chen, Y.X., 2002. Biodegradation and mixing of crude oils in Eocene Es3 reservoirs of the Liaohe basin, northeastern China. American Association of Petroleum Geologists Bulletin 86(10), 1833-1843.

Kotarba, M.J., 2001. Composition and origin of coalbed gases in the Upper Silesian and Lublin Basins, Poland. Organic Geochemistry 32, 163-180.

Kotarba, M.J., Więclaw, D., Dziadzio, P., Kowalski, A., Kosakowski, P., Bilkiewicz, E., 2014. Organic geochemical study of source rocks and natural gas and their genetic correlation in the eastern part of the Polish Outer Carpathians and Palaeozoic-Mesozoic basement. Marine and Petroleum Geology 56, 97-122.

Larter, S.R., Head, I.M., Huang, H., Bennett, B., Jones, M., Aplin, A.C., Murray, A., Erdmann, M., Wilhelms, A., di Primio, R., 2005. Biodegradation, gas destruction and methane generation in deep subsurface petroleum reservoirs: an overview. Petroleum Geology Conference series 6, 633-639.

Larter, S., di Primio, R., 2005. Effects of biodegradation on oil and gas field PVT properties and the origin of oil rimmed gas accumulations. Organic Geochemistry 36, 299-310.

Li, J., Hou, D.J., Li, J.H., Zhang, J.C., Liu, X., Xu, B., 2011. Characteristics and genetic types of natural gas in the eastern sag of the Liaohe Depression. Natural Gas Industry 31(2), 43-47 (in Chinese with English abstract).

Li, M.J., Zhong, N.N., Shi, S.B., Zhu, L., Tang, Y.J., 2013. The origin of trimethyldibenzothiophenes and their application as maturity indicators in sediments from the Liaohe Basin, East China. Fuel 103, 299-307.

Li, X.F., Wang, X.F., Zheng, J.J., Liu, P., Meng, Q., Shi, B.G., 2015. Geochemistry of low maturity gases from the 
Eastern sag of Liaohe Depression, China. Natural Gas Geoscience 26(7), 1365-1375 (in Chinese with English abstract).

Liang, D., Zhang, S., Zhao, M., Wang, F., 2002. Hydrocarbon source rock and stages of reservoir formation in Kuqa Depression, Tarim Basin. Chinese Science Bulletin 47, 62-70 (suppl.).

Liu, Q.Y., Dai, J.X., Li, J., Zhou, Q.H., 2008. Hydrogen isotope composition of natural gas from Tarim basin and its suggestion to deposited environments for source rocks. Science in China (Series B) 51 (2) , 300-311.

Liu, Q.Y., Zhang, T.W., Jin, Z.J., Qin, S.F., Tang, Y.C., Liu, W.H., 2011. Kinetic model of gaseous alkanes formed from coal in a confined system and its application to gas filling history in Kuqa depression, Tarim basin, Northwest China. Acta Geologica Sinica 85 (4), 911-922.

Liu Q.Y., Worden, R.H., Jin, Z.J., Liu, W.H., Li, J., Gao, B., Zhang, D.W., Hu, A.P., Yang, C., 2013. TSR versus non-TSR process and their impact on gas geochemistry and carbon isotopes in Carboniferous, Permian and Lower Triassic marine carbonate gas reservoirs in the Eastern Sichuan Basin. Geochimica et Cosmochimica Acta $100,96-115$.

Liu, W.H., Xu, Y.C., Wu, T.S., 1993. Application of the natural gas carbon isotopes in the migration- A case study in the Liaohe Basin. Chinese Science Bulletin 38(11),1018-1019 (in Chinese).

Martini, A.M., Walter, L.M., Mclntosh, J.C., 2008. Identification of microbial and thermogenic gas components from Upper Devonian black shale cores, Illinois and Michigan basins. American Association of Petroleum Geologists Bulletin 92(3), 327-339.

Osborn, S,G., \& Mclntosh, J,C., 2010. Chemical and isotopic tracers of the contribution of microbial gas in Devonian organic-rich shales and reservoir sandstones, northern Appalachian Basin. Applied Geochemistry $25,456-471$.

Pallasser, R.J., 2000. Recognising biodegradation in gas/oil accumulations through the ${ }^{13} \mathrm{C}$ compositions of gas components. Organic Geochemistry 31, 1363-1373.

Prinzhofer, A., \& Pernaton, E’., 1997. Isotopically light methane in natural gas: bacterial imprint or diffusive fractionation? Chemical Geology, 142, 193-200.

Rice, D.D., \& Claypool, G.E., 1981. Generation, accumulation, and resource potential of biogenic gas. American Association of Petroleum Geologists Bulletin 65, 5-25.

Rice, D. D., 1993, Controls, habitat, and resource potential of ancient bacterial gas, in R. Vially, ed., Bacterial gas: Paris, Editions Technip, p. 91- 118.

Rooney, M.A., Claypool, G.E., Chung, H.M., Moses, H., 1995. Modeling thermogenic gas generation using carbon 
isotopic ratios of natural gas hydrocarbons. Chemical Geology 126 (3-4), 219-232.

Schoell, M., 1980. The hydrogen and carbon isotopic composition of methane from natural gases of various origins. Geochimica et Cosmochimica Acta 44, 649-661.

Schoell, M., 1983. Genetic characterization of natural gas. American Association of Petroleum Geologists Bulletin 67, 2225-2238.

Schoell, M., 1988. Multiple origins of methane in the earth. Chemical Geology 71, 1-10.

Stahl, W.J., Carey, B.D., 1975. Source-rock identification by isotope analyses of natural gases form fields in the Verde and Dclaware, West Texas. Chemical Geology 164, 257-267.

Stahl, W.J., 1977. Carbon and nitrogen isotopes in hydrocarbon research and exploration. Chemical Geology 20, 121-149.

Tilley, B., Muehlenbachs, K., 2006. Gas maturity and alteration systematics across the estern Canada Sedimentary Basin from four mud gas isotope depth profiles. Organic Geochemistry 37, 1857-1868.

Tuo, J.C., Wang, X.B., Chen, J.F., Simoneit, B.R.T., 2003. Aliphatic and diterpenoid hydrocarbons and their individual carbon isotope compositions in coals from the Liaohe Basin, China. Organic Geochemistry 34, 1615-1625.

Valentine, D.L., Chidthaisong, A., Rice, A., Reeburg, W.S., Tyler, C., 2004. Carbon and hydrogen isotope fractionation by moderately termophilic methanogens. Geochimica et Cosmochimica Acta 68, 1571-1590.

Whiticar, M.J., Faber, E., Schoell, M., 1986. Bogenic methane formation in marine and freshwater environments: $\mathrm{CO}_{2}$ reduction vs. acetate fermentation- Isotope evidence. Geochimica et Cosmochimica Acta 50, 693-709.

Whiticar, M.J., 1999. Carbon and hydrogen isotope systematics of bacterial formation and oxidation of methane. Chemical Geology 161, 291-314.

Xu, S., Nakai, S., Wakita, H., Xu, Y., \& Wang, X., 1997. Carbon isotopes of hydrocarbons and carbon dioxide in natural gases in China. Journal of Asian Earth Sciences, 15, 89-101.

Xu, Y.C., Liu, W.H., Shen, P., Wu, T.S., Wang, W.C., Pu, M.Z., 1993. Formation and Evolution of the Natural gases in the Liaohe Basin. Beijing, Science Press. p. 1-9, 92-113 (in Chinese).

Xu, Y.C., Shen, P., 1996. A study of natural gas origins in China. AAPG Bulletin 80 (10), 1604-1614.

Zhai, G.M., 1991. China Petroleum Geology (Volum 3): Liaohe Depression. Beijing, Petroleum Industry Press, p. 56-89, 218-231 (in Chinese).

Zhang, Z.W., Chen, Z.Y., Guo, K.W., Chen, Y.C., 2002. Natural gas geology of the Liaohe Basin. Beijing, Geological Publishing House, p. 11-36, 82-98 (in Chinese). 
Zhang, Z.W., Gao, Q.S., Wu, T.S., 1995. Geochemical characteristics and genetic origin of the natural gases in the Eastern depression of the Liaohe Basin. Natural Gas Geoscience 27(6), 1-8 (in Chinese). 
Table 1. Geochemical characteristics of the Paleogene source rocks in the Liaohe Basin (Zhang et al., 2002; Hu et al., 2005; Gu, 2016)

\begin{tabular}{|c|c|c|c|c|c|c|c|}
\hline \multirow{3}{*}{$\begin{array}{l}\text { Items } \\
\text { Strata } \\
\end{array}$} & \multicolumn{4}{|l|}{ Western Depression } & \multicolumn{3}{|l|}{ Eastern Depression } \\
\hline & \multicolumn{2}{|c|}{ Main source rocks } & \multicolumn{2}{|c|}{$\begin{array}{c}\text { Secondary } \\
\text { source rocks }\end{array}$} & \multirow{2}{*}{$\begin{array}{c}\text { Main source rocks } \\
E_{2} \mathrm{~s}^{3}\end{array}$} & \multicolumn{2}{|c|}{ Secondary source rocks } \\
\hline & $\mathrm{E}_{2} \mathrm{~s}^{4}$ & $\mathrm{E}_{2} \mathrm{~s}^{3}$ & $\mathrm{E}_{3} \mathrm{~s}^{1-2}$ & $\mathrm{E}_{3} \mathrm{~d}$ & & $\mathrm{E}_{3} \mathrm{~s}^{1-2}$ & $\mathrm{E}_{3} \mathrm{~d}$ \\
\hline $\begin{array}{c}\text { Area of } \\
\text { source rock }\left(\mathrm{km}^{2}\right)\end{array}$ & 2399.1 & 2310.8 & 2119.9 & 1742 & 2596.8 & 3002.9 & 3290 \\
\hline Thickness (m) & 255 & 522 & 252 & 438 & 238 & 238 & 387 \\
\hline $\begin{array}{c}\text { TOC range } \\
\text { /average }(\%)\end{array}$ & $0.5-6.0 / 2.83$ & $0.5-5.0 / 1.99$ & $0.5-3.0 / 1.85$ & $0.5-3.2 / 1.07$ & $0.5-3.0 / 1.94$ & $0.5-2.0 / 1.09$ & $\begin{array}{c}0.3-0.5 / \\
0.38\end{array}$ \\
\hline Kerogen type & dominate in II-I & dominate in I-II & I, II, III & dominate in II -III & dominate in II-III & dominate in III-II & III-II \\
\hline Maturity $\left(\mathrm{R}_{\mathrm{o}}, \%\right)$ & $0.5-2.0$ & $0.5-1.3$ & $0.5-0.8$ & $0.5-0.6$ & $0.7-1.3$ & $0.5-0.7$ & $<0.5$ \\
\hline
\end{tabular}

Table 2. Molecular composition of the Paleogene natural gases in the Liaohe Basin

\begin{tabular}{|c|c|c|c|c|c|c|c|c|c|c|c|c|c|}
\hline \multirow[t]{2}{*}{ Depression } & \multirow{2}{*}{$\begin{array}{c}\text { Oil+gas } \\
\text { field }\end{array}$} & \multirow{2}{*}{ Well } & \multirow{2}{*}{$\begin{array}{c}\text { Reser- } \\
\text { voir }\end{array}$} & \multirow{2}{*}{ Depth (m) } & \multicolumn{7}{|c|}{ Main component (\%) } & \multirow{2}{*}{$\begin{array}{c}\text { Dryness } \\
C_{1} / C_{1-5}\end{array}$} & \multirow{2}{*}{ Data source } \\
\hline & & & & & $\mathbf{C H}_{4}$ & $\mathrm{C}_{2} \mathrm{H}_{6}$ & $\mathrm{C}_{3} \mathrm{H}_{8}$ & $i \mathbf{C}_{4} \mathbf{H}_{10}$ & $n \mathrm{C}_{4} \mathrm{H}_{10}$ & $\mathrm{CO}_{2}$ & $\mathbf{N}_{2}$ & & \\
\hline \multirow[t]{8}{*}{ Eastern } & \multirow{6}{*}{$\begin{array}{l}\text { Huang } \\
\text { Jindai }\end{array}$} & $\mathrm{H} 23$ & $\mathrm{E}_{3} \mathrm{~d}$ & $1644.4-1786.0$ & 94.99 & 4.30 & 0.31 & 0.17 & 0.06 & n.d. & 0.02 & 0.951 & This paper \\
\hline & & $\mathrm{H} 23$ & $\mathrm{E}_{3} \mathrm{~d}$ & $1700-1786$ & 93.93 & 4.93 & 0.14 & 0.04 & 0.05 & 0.07 & 0.78 & 0.948 & Li et al., 2015 \\
\hline & & $\mathrm{H} 26$ & $\mathrm{E}_{3} \mathrm{~d}$ & $1578.2-1702.0$ & 95.59 & 3.43 & 0.35 & 0.10 & 0.06 & n.d. & 0.41 & 0.960 & This paper \\
\hline & & $\mathrm{H} 26$ & $\mathrm{E}_{3} \mathrm{~d}$ & $1678.0-1770.0$ & n.d. & n.d. & n.d. & n.d. & n.d. & n.d. & n.d. & n.d. & \multirow{2}{*}{ Zhang et al., 1995} \\
\hline & & H105 & $\mathrm{E}_{3} \mathrm{~d}$ & $1335.0-1354.0$ & 99.84 & \multicolumn{4}{|c|}{$0.11\left(\mathrm{C}_{2}-\mathrm{C}_{4}\right)$} & 0.00 & 0.05 & 0.999 & \\
\hline & & H11-10 & $\mathrm{E}_{3} \mathrm{~d}$ & 2064 & 91.33 & 2.94 & 2.39 & \multicolumn{2}{|c|}{$2.57\left(i \mathrm{C}_{4}-n \mathrm{C}_{4}\right)$} & n.d. & 1.24 & 0.920 & Chen et al., 1998 \\
\hline & \multirow{2}{*}{ Niuju } & N13 & $\mathrm{E}_{3} \mathrm{~d}$ & $1793.4-1827.8$ & 96.83 & \multicolumn{4}{|c|}{$1.67\left(\mathrm{C}_{2}-\mathrm{C}_{4}\right)$} & 0.00 & 1.46 & 0.983 & Zhang et al., 1995 \\
\hline & & N21-020 & $\mathrm{E}_{3} \mathrm{~d}$ & 1688.4-1978.1 & 96.38 & 2.33 & 0.61 & 0.25 & 0.16 & 0.07 & 0.03 & 0.966 & This paper \\
\hline
\end{tabular}




\begin{tabular}{|c|c|c|c|c|c|c|c|c|c|c|c|c|c|}
\hline & & N22-020 & $\mathrm{E}_{3} \mathrm{~d}$ & $1688.0-2023.6$ & 94.48 & 3.32 & 0.94 & 0.29 & 0.19 & 0.10 & 0.55 & 0.952 & \\
\hline & & $\mathrm{N} 22-320$ & $\mathrm{E}_{3} \mathrm{~d}$ & 1706.6-1773.0 & 98.53 & 1.01 & 0.20 & 0.08 & 0.05 & & 0.08 & 0.987 & \\
\hline & & N22-022 & $\mathrm{E}_{3} \mathrm{~d}$ & 1894-1908 & 87.74 & 8.26 & 1.28 & 0.14 & 0.44 & 0.19 & 1.62 & 0.897 & \\
\hline \multirow[t]{25}{*}{ Eastern } & & $\mathrm{N} 23-22$ & $\mathrm{E}_{3} \mathrm{~d}$ & $1935-2076$ & 63.24 & 12.76 & 12.94 & 2.78 & 3.65 & 0.11 & 0.86 & 0.663 & Li et al., 2015 \\
\hline & \multirow{5}{*}{$\begin{array}{c}\text { Rong } \\
\text { Xingtun }\end{array}$} & R6 & $\mathrm{E}_{3} \mathrm{~d}$ & $1537-1539$ & 96.67 & 1.99 & 0.26 & 0.25 & 0.10 & 0.07 & 0.59 & 0.974 & \\
\hline & & R64 & $\mathrm{E}_{3} \mathrm{~d}$ & $1292.25-1295.25$ & 97.91 & 1.98 & 0.05 & 0.02 & 0.01 & 0.00 & 0.04 & 0.979 & \multirow{2}{*}{ Zhang et al., 1995} \\
\hline & & $\mathrm{R} 80$ & $\mathrm{E}_{3} \mathrm{~d}$ & $2154.5-2146.0$ & 70.49 & \multicolumn{4}{|c|}{$28.61\left(\mathrm{C}_{2}-\mathrm{C}_{4}\right)$} & 0.21 & 0.00 & 0.711 & \\
\hline & & R161-25 & $\mathrm{E}_{3} \mathrm{~d}$ & 1905.6-1921.1 & 92.88 & 4.46 & 1.57 & 0.30 & 0.40 & 0.06 & 0.04 & 0.932 & \multirow{2}{*}{ This paper } \\
\hline & & R201-19c & $\mathrm{E}_{3} \mathrm{~d}$ & $1710.4-1726.5$ & 97.18 & 2.62 & 0.07 & 0.05 & 0.00 & 0.06 & 0.01 & 0.972 & \\
\hline & Taoyuan & $\mathrm{T} 7$ & $\mathrm{E}_{3} \mathrm{~d}$ & $1270.1-1273.0$ & 99.64 & \multicolumn{4}{|c|}{$0.20\left(\mathrm{C}_{2}-\mathrm{C}_{4}\right)$} & 0.00 & 0.16 & 0.998 & \multirow{2}{*}{ Zhang et al., 1995} \\
\hline & Dapingfang & D11-16 & $\mathrm{E}_{3} \mathrm{~d}$ & 1887.4-1907.0 & n.d. & n.d. & n.d. & n.d. & n.d. & n.d. & n.d. & & \\
\hline & \multirow{2}{*}{ Hongxing } & H8-12 & $\mathrm{E}_{3} \mathrm{~d}$ & $1737-1761$ & 68.67 & 17.23 & 7.93 & 1.22 & 1.85 & n.d. & 1.10 & 0.709 & \multirow{2}{*}{ Li et al., 2015} \\
\hline & & H5 & $\mathrm{E}_{3} \mathrm{~d}$ & $2365-2370$ & 72.94 & 12.09 & 7.26 & 1.45 & 2.30 & n.d. & 1.53 & 0.759 & \\
\hline & Kuihuaao & KH8 & $\mathrm{E}_{3} \mathrm{~d}$ & $2417.0-2426.0$ & n.d. & n.d. & n.d. & n.d. & n.d. & n.d. & n.d. & & Zhang et al., 1995 \\
\hline & \multirow{5}{*}{ Huangjindai } & $\mathrm{H} 34$ & $\mathrm{E}_{3} \mathrm{~s}^{1}$ & 2527 & 73.21 & 6.09 & 11.83 & \multicolumn{2}{|c|}{$7.72\left(i \mathrm{C}_{4}-n \mathrm{C}_{4}\right)$} & 0.54 & n.d. & 0.741 & Chen et al., 1998 \\
\hline & & $\mathrm{H} 81$ & $\mathrm{E}_{3} \mathrm{~s}^{1}$ & $3065.0-3130.0$ & n.d. & n.d. & n.d. & n.d. & n.d. & n.d. & n.d. & & \multirow{3}{*}{ Zhang et al., 1995} \\
\hline & & H105 & $\mathrm{E}_{3} \mathrm{~s}^{1}$ & $1380-1384$ & 99.51 & n.d. & n.d. & n.d. & n.d. & 0.02 & 0.38 & 1.000 & \\
\hline & & $\mathrm{H} 24$ & $\mathrm{E}_{3} \mathrm{~s}^{1}$ & $2287-2502$ & 98.26 & 0.48 & 0.03 & 0.01 & 0.01 & 0.09 & 0.67 & 0.995 & \\
\hline & & H9-15 & $\mathrm{E}_{3} \mathrm{~s}^{1}$ & $2616.5-2836.7$ & 88.43 & 6.97 & 2.97 & 0.56 & 0.63 & 0.13 & 0.05 & 0.888 & This paper \\
\hline & \multirow{5}{*}{ Rehetai } & R11 & $\mathrm{E}_{3} \mathrm{~s}^{1}$ & $1416-1487$ & 98.70 & 0.93 & 0.05 & 0.02 & n.d. & 0.01 & 0.28 & 0.990 & \multirow{2}{*}{ Li et al., 2015} \\
\hline & & RQ2 & $\mathrm{E}_{3} \mathrm{~s}^{1}$ & $1594-1661$ & 98.63 & 0.80 & 0.05 & n.d. & n.d. & 0.04 & 0.46 & 0.991 & \\
\hline & & R19-6 & $\mathrm{E}_{3} \mathrm{~s}^{1}$ & $1616.5-1656.9$ & 98.34 & 1.00 & 0.17 & 0.01 & 0.04 & 0.20 & 0.03 & 0.988 & $T^{\circ}$ \\
\hline & & R44 & $\mathrm{E}_{3} \mathrm{~s}^{1}$ & $1662.1-1714.5$ & 91.96 & 3.10 & 3.00 & 0.66 & 0.77 & n.d. & 0.02 & 0.924 & 1nis paper \\
\hline & & R44 & $\mathrm{E}_{3} \mathrm{~s}^{1}$ & $1662-1715$ & 88.42 & 6.72 & 1.87 & 0.26 & 0.68 & 0.35 & 0.35 & 0.903 & Li et al., 2015 \\
\hline & \multirow{2}{*}{ Niuju } & $\mathrm{N} 23-22$ & $\mathrm{E}_{3} \mathrm{~s}^{1}$ & 2276 & 90.34 & 1.43 & 3.35 & \multicolumn{2}{|c|}{$2.14\left(i \mathrm{C}_{4}-n \mathrm{C}_{4}\right)$} & n.d. & 2.75 & 0.929 & Chen et al., 1998 \\
\hline & & $\mathrm{N} 23-23$ & $\mathrm{E}_{3} \mathrm{~s}^{1}$ & $2257-2276$ & 90.34 & 1.43 & 3.35 & 0.71 & 0.91 & 0 & 2.75 & 0.934 & \multirow{3}{*}{ Li et al., 2015} \\
\hline & \multirow{2}{*}{ Rongxingtun } & R56 & $\mathrm{E}_{3} \mathrm{~s}^{1}$ & $2476-2483$ & 84.56 & 8.23 & 4.75 & 0.83 & 0.74 & 0.49 & 0 & 0.853 & \\
\hline & & R66 & $\mathrm{E}_{3} \mathrm{~S}^{1}$ & $2687-2891$ & 96.59 & 0.91 & 1.26 & 0.21 & 0.45 & 0.01 & 0.27 & 0.972 & \\
\hline
\end{tabular}




\begin{tabular}{|c|c|c|c|c|c|c|c|c|c|c|c|c|c|}
\hline \multirow{23}{*}{ Eastern } & & R66 & $E_{3} s^{1}$ & 2813.1-2828.4 & n.d. & n.d. & n.d. & n.d. & n.d. & n.d. & n.d. & & Zhang et al., 1995 \\
\hline & Yushutai & T601 & $\mathrm{E}_{3} \mathrm{~s}^{1}$ & 2196.3-2258.4 & 92.78 & 3.58 & 1.93 & 0.41 & 0.57 & 0.12 & 0.06 & 0.935 & This paper \\
\hline & Taoyuan & $\mathrm{T} 17$ & $E_{3} s^{1}$ & $2346.0-2353.0$ & 87.08 & \multicolumn{4}{|c|}{$11.90\left(\mathrm{C}_{2}-\mathrm{C}_{4}\right)$} & 0.31 & 0.55 & 0.880 & \multirow{5}{*}{ Zhang et al., 1995} \\
\hline & Dapingfang & D32 & $\mathrm{E}_{3} \mathrm{~s}^{1}$ & $3011.3-3019.0$ & 88.14 & \multicolumn{4}{|c|}{$9.87\left(\mathrm{C}_{2}-\mathrm{C}_{4}\right)$} & 0.46 & 1.38 & 0.899 & \\
\hline & \multirow{2}{*}{ Oulituozi } & O6 & $\mathrm{E}_{3} \mathrm{~s}^{1}$ & 2227.5-2267.0 & 93.61 & \multicolumn{4}{|c|}{$4.24\left(\mathrm{C}_{2}-\mathrm{C}_{4}\right)$} & 0.34 & 1.66 & 0.957 & \\
\hline & & L12 & $\mathrm{E}_{3} \mathrm{~s}^{1}$ & 1579.3-1591.2 & 92.22 & \multicolumn{4}{|c|}{$5.80\left(\mathrm{C}_{2}-\mathrm{C}_{4}\right)$} & 0.00 & 1.98 & 0.941 & \\
\hline & \multirow{2}{*}{ Yulou } & Y4-3 & $E_{3} s^{1}$ & 1831.0-2192.0 & n.d. & n.d. & n.d. & n.d. & n.d. & n.d. & n.d. & & \\
\hline & & Y9 & $\mathrm{E}_{3} \mathrm{~s}^{1}$ & $1768-1782$ & 96.49 & 2.06 & 0.60 & 0.07 & 0.12 & 0.00 & 0.62 & 0.971 & Li et al., 2015 \\
\hline & \multirow{5}{*}{ Qinglongtai } & L9 & $\mathrm{E}_{3} \mathrm{~s}^{1}$ & 1376 & 97.85 & 0.68 & 0.41 & \multicolumn{2}{|c|}{$0.01\left(i \mathrm{C}_{4}-n \mathrm{C}_{4}\right)$} & 0.06 & 0.94 & 0.989 & \multirow{3}{*}{ Chen et al., 1998} \\
\hline & & LQ5 & $E_{3} s^{1}$ & 1504 & 97.96 & 0.83 & 0.21 & \multicolumn{2}{|c|}{$0.01\left(i \mathrm{C}_{4}-n \mathrm{C}_{4}\right)$} & 0.26 & 0.88 & 0.989 & \\
\hline & & LQ4 & $\mathrm{E}_{3} \mathrm{~s}^{1}$ & 1706 & 98.36 & 0.56 & 0.1 & \multicolumn{2}{|c|}{$0.01\left(i \mathrm{C}_{4}-n \mathrm{C}_{4}\right)$} & 0.01 & 0.91 & 0.993 & \\
\hline & & L14-21 & $\mathrm{E}_{3} \mathrm{~s}^{1}$ & 1401.0-1431.0 & 93.66 & \multicolumn{4}{|c|}{$5.49\left(\mathrm{C}_{2}-\mathrm{C}_{4}\right)$} & 0.00 & 0.85 & 0.945 & \multirow{3}{*}{ Zhang et al., 1995} \\
\hline & & L20-21 & $\mathrm{E}_{3} \mathrm{~s}^{1}$ & 1435.8-1556.0 & 98.93 & \multicolumn{4}{|c|}{$0.00\left(\mathrm{C}_{2}-\mathrm{C}_{4}\right)$} & 0.00 & 1.08 & & \\
\hline & Rehetai & R20-11 & $\mathrm{E}_{2} \mathrm{~s}^{3}$ & 2286.0-2291.0 & n.d. & n.d. & n.d. & n.d. & n.d. & n.d. & n.d. & & \\
\hline & Yushutai & $\mathrm{T} 28-26$ & $\mathrm{E}_{2} \mathrm{~s}^{3}$ & 2388.7-2392.3 & 93.61 & 3.56 & 1.79 & 0.35 & 0.54 & 0.16 & 0.03 & 0.937 & This paper \\
\hline & Yulou & $\mathrm{X} 10$ & $\mathrm{E}_{2} \mathrm{~s}^{3}$ & 1526 & 98.37 & 0.39 & 0.13 & & $\left.\mathrm{C}_{4}\right)$ & 0.08 & 0.95 & 0.995 & Chen et al., 1998 \\
\hline & \multirow{2}{*}{ Qinglongtai } & L25-16 & $\mathrm{E}_{2} \mathrm{~s}^{3}$ & 1567.0-1580.6 & 98.21 & \multicolumn{4}{|c|}{$0.15\left(\mathrm{C}_{2}-\mathrm{C}_{4}\right)$} & 0.00 & 1.64 & 0.998 & Zhang et al., 1995 \\
\hline & & L26-20 & $\mathrm{E}_{2} \mathrm{~s}^{3}$ & $1700-1734$ & 96.79 & 1.03 & 0.28 & 0.16 & 0.17 & n.d. & 1.44 & 0.983 & \multirow{6}{*}{ Li et al., 2015} \\
\hline & \multirow{2}{*}{ Oulituozi } & O6 & $\mathrm{E}_{2} \mathrm{~s}^{3}$ & $2228-2267$ & 93.60 & 1.55 & 1.62 & 0.45 & 0.40 & 0.34 & 1.66 & 0.959 & \\
\hline & & $\mathrm{O} 13$ & $\mathrm{E}_{2} \mathrm{~s}^{3}$ & $2291-2302$ & 95.50 & 1.19 & 0.79 & 0.26 & 0.25 & 0.06 & 1.76 & 0.975 & \\
\hline & Huangjindai & $\mathrm{H} 202$ & $\mathrm{E}_{2} \mathrm{~s}^{3}$ & $2768-3152$ & 89.05 & 8.80 & 0.27 & 0.00 & 0.02 & 0.85 & 0.83 & 0.907 & \\
\hline & \multirow{2}{*}{ Dapingfang } & D32 & $\mathrm{E}_{2} \mathrm{~s}^{3}$ & 3011-3019 & 88.14 & 6.73 & 2.51 & 0.39 & 0.24 & 0.46 & 0.00 & 0.899 & \\
\hline & & D40 & $\mathrm{E}_{2} \mathrm{~s}^{3}$ & 2079-2095 & 89.40 & 7.76 & 0.94 & 0.12 & 0.31 & 0.05 & 1.22 & 0.907 & \\
\hline \multirow[t]{5}{*}{ Western } & \multirow{5}{*}{ Lengjiapu } & 6 & $\mathrm{E}_{3} \mathrm{~s}^{1}$ & $1387-1495$ & 93.70 & 0.70 & 0.40 & n.d. & n.d. & 3.0 & 1.90 & 0.988 & \multirow{5}{*}{ Huang et al., 2014} \\
\hline & & 7 & $E_{3} s^{1}$ & $1407-1437$ & 97.20 & 0.60 & 0.20 & n.d. & n.d. & 1.40 & 0.10 & 0.992 & \\
\hline & & 8 & $\mathrm{E}_{3} \mathrm{~s}^{1}$ & 1613.6-1650 & 97.10 & 0.80 & 0.30 & n.d. & n.d. & 1.20 & n.d. & 0.989 & \\
\hline & & 9 & $E_{3} s^{1}$ & $1485-1532$ & 96.10 & 0.70 & 0.30 & n.d. & n.d. & 1.30 & 1.50 & 0.990 & \\
\hline & & 10 & $E_{3} s^{1}$ & $1555-1590$ & 93.80 & 0.70 & 1.10 & 0.60 & 1.10 & 2.40 & n.d. & 0.964 & \\
\hline
\end{tabular}




\begin{tabular}{|c|c|c|c|c|c|c|c|c|c|c|c|c|}
\hline & 11 & $\mathrm{E}_{3} \mathrm{~s}^{1}$ & $1590-1620$ & 48.90 & 5.40 & 21.0 & 8.10 & 9.10 & 6.60 & n.d. & 0.529 & \\
\hline & 12 & $E_{3} s^{1}$ & $1334.9-1396.4$ & 94.70 & 2.50 & 0.40 & 0 & n.d. & 1.70 & n.d. & 0.970 & \\
\hline & 15 & $\mathrm{E}_{3} \mathrm{~s}^{1}$ & 1374-1405 & 89.60 & 1.70 & 0.30 & n.d. & n.d. & 1.30 & 5.40 & 0.978 & \\
\hline & 17 & $\mathrm{E}_{3} \mathrm{~s}^{1}$ & $1373-1407.8$ & 97.60 & 1.50 & 0.10 & n.d. & n.d. & 0.80 & n.d. & 0.984 & \\
\hline & 19 & $\mathrm{E}_{3} \mathrm{~s}^{1}$ & 1344.3-1401.5 & 98.40 & 1.20 & 0 & n.d. & n.d. & 0.30 & n.d. & 0.988 & \\
\hline & 20 & $\mathrm{E}_{3} \mathrm{~s}^{1}$ & $1351.2-1487$ & 94.10 & 3.10 & 1.40 & 0.50 & 0.30 & 0.50 & n.d. & 0.947 & \\
\hline & 21 & $E_{3} s^{1}$ & $1338-1382$ & 95.90 & 2.10 & 0.90 & 0.30 & 0.20 & 0 & n.d. & 0.965 & \\
\hline & 22 & $\mathrm{E}_{3} \mathrm{~s}^{1}$ & 1451.8-1541.9 & 94.00 & 3.00 & 1.70 & 0.30 & 0.40 & 0.20 & n.d. & 0.946 & \\
\hline Shuangtaizi & S9 & $\mathrm{E}_{3} \mathrm{~s}^{2}$ & 2821 & 86.96 & 6.20 & 3.75 & \multicolumn{2}{|c|}{$2.57\left(i \mathrm{C}_{4}-n \mathrm{C}_{4}\right)$} & 0.03 & 0.51 & 0.874 & Chen et al.,1998 \\
\hline \multirow{9}{*}{ Lengjiapu } & 1 & $\mathrm{E}_{2} \mathrm{~s}^{3}$ & $2844.7-2885.6$ & 90.40 & 2.10 & 4.70 & 0.80 & 1.30 & 0.60 & n.d. & 0.910 & \multirow{9}{*}{ Huang et al., 2014} \\
\hline & 2 & $\mathrm{E}_{2} \mathrm{~s}^{3}$ & 2688.7-2690.4 & 91.80 & 2.50 & 3.60 & 0.40 & 1.00 & 0.60 & n.d. & 0.924 & \\
\hline & 3 & $\mathrm{E}_{2} \mathrm{~s}^{3}$ & $2758.1-2937.2$ & 87.00 & 3.30 & 6.50 & 1.0 & 1.30 & 0.70 & n.d. & 0.878 & \\
\hline & 4 & $\mathrm{E}_{2} \mathrm{~s}^{3}$ & $1880-1895$ & 90.30 & 1.90 & 4.70 & 0.80 & 1.40 & 0.60 & n.d. & 0.911 & \\
\hline & 5 & $\mathrm{E}_{2} \mathrm{~s}^{3}$ & 1781.2-1838.6 & 97.90 & 1.50 & 0 & n.d. & n.d. & 0.50 & n.d. & 0.985 & \\
\hline & 13 & $\mathrm{E}_{2} \mathrm{~s}^{3}$ & $1740-1802$ & 96.20 & 2.00 & 0.70 & 0.30 & n.d. & 0.40 & n.d. & 0.970 & \\
\hline & 14 & $\mathrm{E}_{2} \mathrm{~s}^{3}$ & $1745-1844$ & 92.40 & 3.10 & 1.60 & 0.30 & 0.30 & 0.10 & 1.90 & 0.946 & \\
\hline & 16 & $\mathrm{E}_{2} \mathrm{~s}^{3}$ & $1619-1746$ & 90.20 & 4.80 & 3.20 & 0.50 & 0.50 & 0.40 & n.d. & 0.909 & \\
\hline & 18 & $\mathrm{E}_{2} \mathrm{~s}^{3}$ & $1611.4-1755$ & 83.40 & 3.80 & 2.20 & 0.20 & 0.30 & 2.00 & 6.90 & 0.928 & \\
\hline Qijia & Q4 & $\mathrm{E}_{2} \mathrm{~s}^{4}$ & 2590 & 70.96 & 13.74 & 8.99 & \multicolumn{2}{|c|}{$5.87\left(i \mathrm{C}_{4}-n \mathrm{C}_{4}\right)$} & 0.86 & n.d. & 0.713 & Chen et al., 1998 \\
\hline
\end{tabular}

Note: n.d.- not determined

Table 3. Stable carbon and hydrogen isotopic compositions of the Paleogene natural gases in the Liaohe Basin

\begin{tabular}{|c|c|c|c|c|c|c|c|c|c|c|c|c|c|c|c|}
\hline \multirow[t]{2}{*}{ Depression } & \multirow{2}{*}{$\begin{array}{c}\text { Oil+gas } \\
\text { field }\end{array}$} & \multirow{2}{*}{ Well } & \multirow{2}{*}{$\begin{array}{c}\text { Reser- } \\
\text { voir }\end{array}$} & \multirow{2}{*}{ Depth (m) } & \multicolumn{7}{|c|}{$\delta^{13} \mathrm{C}(\%, \mathrm{VPDB})$} & \multicolumn{3}{|c|}{$\delta^{2} \mathrm{H}(\%$, VSMOW) } & \multirow{2}{*}{ Data source } \\
\hline & & & & & $\mathbf{C H}_{4}$ & $\mathrm{C}_{2} \mathrm{H}_{6}$ & $\mathrm{C}_{3} \mathrm{H}_{8}$ & $\mathrm{C}_{4} \mathrm{H}_{10}$ & $i \mathrm{C}_{4} \mathrm{H}_{10}$ & $n \mathrm{C}_{4} \mathrm{H}_{10}$ & $\delta^{13} \mathrm{C}_{\mathrm{CO} 2}$ & $\mathbf{C H}_{4}$ & $\mathrm{C}_{2} \mathrm{H}_{6}$ & $\mathrm{C}_{3} \mathrm{H}_{8}$ & \\
\hline \multirow[t]{3}{*}{ Eastern } & \multirow{3}{*}{$\begin{array}{c}\text { Huang } \\
\text { Jindai }\end{array}$} & $\mathrm{H} 23$ & $\mathrm{E}_{3} \mathrm{~d}$ & $1644.4-1786.0$ & -43.2 & -26.2 & -18.7 & -24.3 & -25.3 & -21.5 & -11.6 & -247 & -189 & n.d. & This paper \\
\hline & & $\mathrm{H} 23$ & $\mathrm{E}_{3} \mathrm{~d}$ & $1700-1786$ & -41.5 & -26.5 & -25.8 & n.d. & n.d. & n.d. & -0.5 & -235 & -163 & n.d. & Li et al., 2015 \\
\hline & & $\mathrm{H} 26$ & $\mathrm{E}_{3} \mathrm{~d}$ & $1578.2-1702.0$ & -40.9 & -26.2 & -24.5 & n.d. & n.d. & n.d. & -12.0 & -243 & -190 & -137 & This paper \\
\hline
\end{tabular}




\begin{tabular}{|c|c|c|c|c|c|c|c|c|c|c|c|c|c|c|}
\hline & $\mathrm{H} 26$ & $\mathrm{E}_{3} \mathrm{~d}$ & 1678.0-1770.0 & -41.5 & -27.6 & -22.4 & -24.9 & n.d. & n.d. & n.d. & n.d. & n.d. & n.d. & 7 bonot 1005 \\
\hline & H105 & $\mathrm{E}_{3} \mathrm{~d}$ & $1335.0-1354.0$ & -44.5 & n.d. & n.d. & n.d. & n.d. & n.d. & n.d. & n.d. & n.d. & n.d. & - \\
\hline & H11-10 & $\mathrm{E}_{3} \mathrm{~d}$ & 2064 & -46.4 & -28.7 & -26.6 & n.d. & n.d. & n.d. & n.d. & n.d. & n.d. & n.d. & Chen et al., 1998 \\
\hline \multirow{6}{*}{ Niuju } & N13 & $\mathrm{E}_{3} \mathrm{~d}$ & 1793.4-1827.8 & -43.5 & n.d. & n.d. & n.d. & n.d. & n.d. & n.d. & n.d. & n.d. & n.d. & Zhang et al., 1995 \\
\hline & N21-020 & $\mathrm{E}_{3} \mathrm{~d}$ & 1688.4-1978.1 & -44.2 & -24.8 & -21.1 & -23.6 & -24.6 & -21.9 & 5.5 & -244 & -180 & -169 & \multirow{3}{*}{ This paper } \\
\hline & $\mathrm{N} 22-020$ & $\mathrm{E}_{3} \mathrm{~d}$ & $1688.0-2023.6$ & -42.8 & -25.1 & -23.1 & -25.2 & -26.2 & -23.7 & n.d. & -257 & -190 & -188 & \\
\hline & $\mathrm{N} 22-320$ & $\mathrm{E}_{3} \mathrm{~d}$ & 1706.6-1773.0 & -44.1 & -23.4 & -21.8 & -22.4 & -22.4 & -22.4 & 2.1 & -244 & -170 & n.d. & \\
\hline & N22-022 & $\mathrm{E}_{3} \mathrm{~d}$ & 1894-1908 & -42.1 & -26.4 & -24.9 & n.d. & n.d. & n.d. & -1.3 & -240 & -186 & -163 & \multirow{5}{*}{ Zhang et al., 1995} \\
\hline & $\mathrm{N} 23-22$ & $\mathrm{E}_{3} \mathrm{~d}$ & $1935-2076$ & -40.7 & -27.3 & n.d. & n.d. & n.d. & n.d. & n.d. & -217 & n.d. & n.d. & \\
\hline \multirow{5}{*}{$\begin{array}{c}\text { Rong } \\
\text { Xingtun }\end{array}$} & R6 & $\mathrm{E}_{3} \mathrm{~d}$ & $1537-1539$ & -38.4 & -25.6 & n.d. & n.d. & n.d. & n.d. & n.d. & -220 & n.d. & n.d. & \\
\hline & R64 & $\mathrm{E}_{3} \mathrm{~d}$ & $1292.25-1295.25$ & -41.9 & -24.7 & -24.7 & -22.5 & n.d. & n.d. & n.d. & -219 & n.d. & n.d. & \\
\hline & $\mathrm{R} 80$ & $\mathrm{E}_{3} \mathrm{~d}$ & $2154.5-2146.0$ & -44.5 & -28.9 & -26.3 & -28.5 & n.d. & n.d. & n.d. & n.d. & n.d. & n.d. & \\
\hline & R161-25 & $\mathrm{E}_{3} \mathrm{~d}$ & 1905.6-1921.1 & -36.2 & -26.5 & -24.7 & -24.9 & -25.7 & -24.3 & n.d. & -205 & -186 & -198 & \multirow{2}{*}{ This paper } \\
\hline & R201-19c & $\mathrm{E}_{3} \mathrm{~d}$ & 1710.4-1726.5 & -40.9 & -24.4 & n.d. & n.d. & n.d. & n.d. & n.d. & -233 & -167 & n.d. & \\
\hline Taoyuan & $\mathrm{T} 7$ & $\mathrm{E}_{3} \mathrm{~d}$ & 1270.1-1273.0 & -40.9 & n.d. & n.d. & n.d. & n.d. & n.d. & n.d. & n.d. & n.d. & n.d. & \multirow{2}{*}{ Zhang et al., 1995} \\
\hline Dapingfang & D11-16 & $\mathrm{E}_{3} \mathrm{~d}$ & 1887.4-1907.0 & -38.2 & -26.8 & -24.7 & -25.7 & n.d. & n.d. & n.d. & n.d. & n.d. & n.d. & \\
\hline \multirow{2}{*}{ Hongxing } & H8-12 & $\mathrm{E}_{3} \mathrm{~d}$ & $1737-1761$ & -37.0 & -27.5 & -26.9 & n.d. & n.d. & n.d. & n.d. & -202 & n.d. & n.d. & \multirow{2}{*}{ Li et al., 2015} \\
\hline & H5 & $\mathrm{E}_{3} \mathrm{~d}$ & $2365-2370$ & -39.2 & -28.8 & -26.0 & n.d. & n.d. & n.d. & n.d. & -192 & n.d. & n.d. & \\
\hline Kuihuaao & KH8 & $\mathrm{E}_{3} \mathrm{~d}$ & $2417.0-2426.0$ & -35.8 & -26.6 & -24.5 & -25.3 & n.d. & n.d. & n.d. & n.d. & n.d. & n.d. & Zhang et al., 1995 \\
\hline \multirow{5}{*}{ Huangjindai } & $\mathrm{H} 34$ & $\mathrm{E}_{3} \mathrm{~s}^{1}$ & 2527 & -49.9 & -30.6 & -27.5 & n.d. & n.d. & n.d. & n.d. & n.d. & n.d. & n.d. & Chen et al., 1998 \\
\hline & $\mathrm{H} 81$ & $\mathrm{E}_{3} \mathrm{~s}^{1}$ & $3065.0-3130.0$ & -34.2 & -27.5 & -24.8 & -25.5 & n.d. & n.d. & n.d. & n.d. & n.d. & n.d. & \multirow{3}{*}{ Zhang et al., 1995} \\
\hline & H105 & $E_{3} s^{1}$ & $1380-1384$ & -44.0 & n.d. & n.d. & n.d. & n.d. & n.d. & n.d. & n.d. & n.d. & n.d. & \\
\hline & $\mathrm{H} 24$ & $\mathrm{E}_{3} \mathrm{~s}^{1}$ & $2287-2502$ & -41.1 & -26.0 & -27.5 & n.d. & n.d. & n.d. & -4.3 & -224 & n.d. & n.d. & \\
\hline & H9-15 & $\mathrm{E}_{3} \mathrm{~s}^{1}$ & $2616.5-2836.7$ & -37.9 & -25.9 & -24.1 & -24.5 & -25.9 & -23.2 & -3.2 & -214 & -196 & -191 & This paper \\
\hline \multirow{4}{*}{ Rehetai } & R11 & $\mathrm{E}_{3} \mathrm{~s}^{1}$ & $1416-1487$ & -45.7 & -26.6 & -27.5 & n.d. & n.d. & n.d. & n.d. & -231 & -157 & n.d. & \multirow{2}{*}{ Li et al., 2015} \\
\hline & RQ2 & $\mathrm{E}_{3} \mathrm{~s}^{1}$ & $1594-1661$ & -49.4 & -38.7 & -27.2 & n.d. & n.d. & n.d. & n.d. & -234 & -193 & n.d. & \\
\hline & R19-6 & $\mathrm{E}_{3} \mathrm{~s}^{1}$ & 1616.5-1656.9 & -44.3 & -22.3 & -21.1 & -23.5 & -21.5 & -23.9 & n.d. & -256 & -174 & -155 & \multirow{2}{*}{ This paper } \\
\hline & R44 & $\mathrm{E}_{3} \mathrm{~s}^{1}$ & 1662.1-1714.5 & -53.5 & -30.4 & -27.0 & -27.2 & -28.9 & -25.7 & n.d. & -261 & -246 & -203 & \\
\hline
\end{tabular}




\begin{tabular}{|c|c|c|c|c|c|c|c|c|c|c|c|c|c|c|}
\hline & R44 & $E_{3} s^{1}$ & $1662-1715$ & -49.3 & -38.7 & -27.2 & n.d. & n.d. & n.d. & n.d. & -234 & -193 & n.d. & Li et al., 2015 \\
\hline \multirow{2}{*}{ Niuju } & $\mathrm{N} 23-22$ & $E_{3} s^{1}$ & 2276 & -40.8 & -27.3 & -24.5 & n.d. & n.d. & n.d. & n.d. & n.d. & n.d. & n.d. & Chen et al., 1998 \\
\hline & $\mathrm{N} 23-23$ & $\mathrm{E}_{3} \mathrm{~s}^{1}$ & $2257-2276$ & -42.1 & -26.4 & -24.9 & n.d. & n.d. & n.d. & -1.3 & -240 & -186 & -163 & \multirow{3}{*}{ Li et al., 2015} \\
\hline \multirow{3}{*}{ Rongxingtun } & R56 & $E_{3} s^{1}$ & $2476-2483$ & -38.4 & -28.6 & -25.9 & -26.4 & n.d. & n.d. & n.d. & n.d. & n.d. & n.d. & \\
\hline & R66 & $E_{3} s^{1}$ & $2687-2891$ & -38.3 & -28.6 & -25.4 & -24.4 & n.d. & n.d. & -5.3 & -213 & -188 & -155 & \\
\hline & R66 & $E_{3} s^{1}$ & 2813.1-2828.4 & -34.8 & -27.7 & -25.1 & -25.6 & n.d. & n.d. & n.d. & n.d. & n.d. & n.d. & Zhang et al., 1995 \\
\hline Yushutai & T601 & $\mathrm{E}_{3} \mathrm{~s}^{1}$ & 2196.3-2258.4 & -40.3 & -26.0 & -23.9 & -24.1 & -25.7 & -22.9 & 0.1 & -211 & -189 & -183 & This paper \\
\hline Taoyuan & $\mathrm{T} 17$ & $E_{3} s^{1}$ & $2346.0-2353.0$ & -40.7 & n.d. & n.d. & n.d. & n.d. & n.d. & n.d. & n.d. & n.d. & n.d. & \multirow{5}{*}{ Zhang et al., 1995} \\
\hline Dapingfang & D32 & $E_{3} s^{1}$ & 3011.3-3019.0 & -41.8 & -26.8 & -24.5 & -25.1 & n.d. & n.d. & n.d. & n.d. & n.d. & n.d. & \\
\hline \multirow{2}{*}{ Oulituozi } & O6 & $E_{3} s^{1}$ & 2227.5-2267.0 & -40.4 & n.d. & n.d. & n.d. & n.d. & n.d. & n.d. & n.d. & n.d. & n.d. & \\
\hline & L12 & $E_{3} s^{1}$ & 1579.3-1591.2 & -60.7 & n.d. & n.d. & n.d. & n.d. & n.d. & n.d. & n.d. & n.d. & n.d. & \\
\hline \multirow{2}{*}{ Yulou } & Y4-3 & $E_{3} s^{1}$ & 1831.0-2192.0 & -44.7 & -30.9 & -26.8 & -26.9 & n.d. & n.d. & n.d. & n.d. & n.d. & n.d. & \\
\hline & Y9 & $E_{3} \mathrm{~s}^{1}$ & 1768-1782 & -52.2 & -33.6 & -27.4 & -25.4 & n.d. & n.d. & n.d. & -248 & -227 & -173 & Li et al., 2015 \\
\hline \multirow{5}{*}{ Qinglongtai } & L9 & $E_{3} \mathrm{~s}^{1}$ & 1376 & -52.6 & -35.5 & -24.9 & n.d. & n.d. & n.d. & n.d. & n.d. & n.d. & n.d. & \multirow{3}{*}{ Chen et al., 1998} \\
\hline & LQ5 & $\mathrm{E}_{3} \mathrm{~s}^{1}$ & 1504 & -55.5 & -47.3 & -40.3 & n.d. & n.d. & n.d. & n.d. & n.d. & n.d. & n.d. & \\
\hline & LQ4 & $E_{3} \mathrm{~s}^{1}$ & 1706 & -52.2 & -39.9 & -38.4 & n.d. & n.d. & n.d. & n.d. & n.d. & n.d. & n.d. & \\
\hline & L14-21 & $\mathrm{E}_{3} \mathrm{~s}^{1}$ & 1401.0-1431.0 & -52.0 & n.d. & n.d. & n.d. & n.d. & n.d. & n.d. & n.d. & n.d. & n.d. & \multirow{3}{*}{ Zhang et al., 1995} \\
\hline & L20-21 & $E_{3} \mathrm{~s}^{1}$ & $1435.8-1556.0$ & -50.3 & n.d. & n.d. & n.d. & n.d. & n.d. & n.d. & n.d. & n.d. & n.d. & \\
\hline Rehetai & R20-11 & $\mathrm{E}_{2} \mathrm{~s}^{3}$ & 2286.0-2291.0 & -49.6 & -31.0 & -27.9 & n.d. & n.d. & n.d. & n.d. & n.d. & n.d. & n.d. & \\
\hline Yushutai & $\mathrm{T} 28-26$ & $\mathrm{E}_{2} \mathrm{~s}^{3}$ & 2388.7-2392.3 & -34.5 & -26.6 & -24.1 & -24.4 & -25.9 & -23.4 & -0.7 & -188 & -187 & -179 & This paper \\
\hline Yulou & $\mathrm{X} 10$ & $\mathrm{E}_{2} \mathrm{~s}^{3}$ & 1526 & -59.3 & -39.8 & -30.0 & n.d. & n.d. & n.d. & n.d. & n.d. & n.d. & n.d. & Chen et al., 1998 \\
\hline \multirow{2}{*}{ Qinglongtai } & L25-16 & $\mathrm{E}_{2} \mathrm{~s}^{3}$ & 1567.0-1580.6 & -50.6 & n.d. & n.d. & n.d. & n.d. & n.d. & n.d. & n.d. & n.d. & n.d. & Zhang et al., 1995 \\
\hline & L26-20 & $\mathrm{E}_{2} \mathrm{~s}^{3}$ & $1700-1734$ & -47.9 & n.d. & n.d. & n.d. & n.d. & n.d. & n.d. & -224 & n.d. & n.d. & \multirow{6}{*}{ Li et al., 2015} \\
\hline \multirow{2}{*}{ Oulituozi } & O6 & $\mathrm{E}_{2} \mathrm{~s}^{3}$ & $2228-2267$ & -40.4 & -28.8 & -27.0 & -26.9 & n.d. & n.d. & n.d. & n.d. & n.d. & n.d. & \\
\hline & $\mathrm{O} 13$ & $\mathrm{E}_{2} \mathrm{~s}^{3}$ & $2291-2302$ & -41.0 & -29.7 & -27.8 & -27.3 & n.d. & n.d. & n.d. & -215 & n.d. & n.d. & \\
\hline Huangjindai & $\mathrm{H} 202$ & $\mathrm{E}_{2} \mathrm{~s}^{3}$ & $2768-3152$ & -44.6 & -29.5 & -23.5 & n.d. & n.d. & n.d. & -4.9 & -250 & -209 & -106 & \\
\hline \multirow{2}{*}{ Dapingfang } & D32 & $\mathrm{E}_{2} \mathrm{~s}^{3}$ & 3011-3019 & -41.8 & -26.8 & -24.5 & -25.1 & n.d. & n.d. & n.d. & n.d. & n.d. & n.d. & \\
\hline & D40 & $\mathrm{E}_{2} \mathrm{~s}^{3}$ & 2079-2095 & -36.2 & -26.1 & -23.4 & -22.3 & n.d. & n.d. & n.d. & -191 & -154 & -131 & \\
\hline
\end{tabular}




\begin{tabular}{|c|c|c|c|c|c|c|c|c|c|c|c|c|c|c|c|}
\hline \multirow[t]{24}{*}{ Western } & & 6 & $E_{3} \mathrm{~s}^{1}$ & $1387-1495$ & -53.6 & -38.3 & -28.2 & n.d. & n.d. & n.d. & 9.0 & -232 & n.d. & n.d. & \multirow{13}{*}{ Huang et al., 2014} \\
\hline & \multirow{12}{*}{ Lengjiapu } & 7 & $E_{3} s^{1}$ & $1407-1437$ & -50.9 & -39.0 & -29.9 & n.d. & n.d. & n.d. & 7.3 & -231 & n.d. & n.d. & \\
\hline & & 8 & $\mathrm{E}_{3} \mathrm{~s}^{1}$ & $1613.6-1650$ & -50.5 & -37.9 & -28.7 & n.d. & n.d. & n.d. & 1.8 & -234 & n.d. & n.d. & \\
\hline & & 9 & $\mathrm{E}_{3} \mathrm{~s}^{1}$ & $1485-1532$ & -55.4 & -39.4 & -29.4 & -23.3 & -25.1 & -21.4 & 1.1 & -233 & n.d. & n.d. & \\
\hline & & 10 & $\mathrm{E}_{3} \mathrm{~s}^{1}$ & $1555-1590$ & -54.8 & -38.3 & -27.6 & -26.7 & -28.3 & -25.9 & 7.7 & -222 & -186 & -182 & \\
\hline & & 11 & $E_{3} s^{1}$ & $1590-1620$ & -53.9 & -31.2 & -26.8 & -26.2 & -27.9 & -24.7 & 10.2 & -234 & -202 & -185 & \\
\hline & & 12 & $E_{3} s^{1}$ & 1334.9-1396.4 & -38.0 & -28.6 & n.d. & n.d. & n.d. & n.d. & 10.4 & -224 & n.d. & n.d. & \\
\hline & & 15 & $\mathrm{E}_{3} \mathrm{~s}^{1}$ & $1374-1405$ & -36.8 & -29.5 & n.d. & n.d. & n.d. & n.d. & 6.9 & -221 & n.d. & n.d. & \\
\hline & & 17 & $\mathrm{E}_{3} \mathrm{~s}^{1}$ & $1373-1407.8$ & -43.4 & -29.8 & -16.4 & n.d. & n.d. & n.d. & 14.5 & -221 & n.d. & n.d. & \\
\hline & & 19 & $E_{3} s^{1}$ & 1344.3-1401.5 & -43.9 & -29.3 & -16.8 & -25.7 & -28.1 & -23.3 & -12.0 & -209 & -148 & n.d. & \\
\hline & & 20 & $E_{3} s^{1}$ & $1351.2-1487$ & -43.2 & -29.4 & -22.8 & -26.8 & -29.0 & -23.0 & 8.4 & -219 & -173 & -130 & \\
\hline & & 21 & $E_{3} s^{1}$ & $1338-1382$ & -44.0 & -29.4 & -20.7 & -25.6 & -29.1 & -20.4 & -7.8 & -216 & -162 & -123 & \\
\hline & & 22 & $\mathrm{E}_{3} \mathrm{~s}^{1}$ & $1451.8-1541.9$ & -43.3 & -28.5 & -23.6 & -26.2 & -29.7 & -23.5 & 8.4 & -225 & -178 & -144 & \\
\hline & Shuangtaizi & S9 & $E_{3} s^{2}$ & 2821 & -40.5 & -28.1 & -26.9 & n.d. & n.d. & n.d. & n.d. & n.d. & n.d. & n.d. & Chen et al.,1998 \\
\hline & & 1 & $\mathrm{E}_{2} \mathrm{~s}^{3}$ & 2844.7-2885.6 & -49.8 & -33.0 & -28.4 & -27.3 & -31.1 & -24.9 & -2.5 & -248 & -264 & -228 & \\
\hline & & 2 & $\mathrm{E}_{2} \mathrm{~s}^{3}$ & 2688.7-2690.4 & -49.1 & -32.4 & -28.5 & -32.5 & -32.5 & n.d. & -0.4 & -256 & n.d. & n.d. & \\
\hline & & 3 & $\mathrm{E}_{2} \mathrm{~s}^{3}$ & 2758.1-2937.2 & -47.9 & -31.1 & -27.4 & -26.0 & -28.1 & -24.3 & 0.9 & -225 & -257 & -212 & \\
\hline & & 4 & $\mathrm{E}_{2} \mathrm{~s}^{3}$ & 1880-1895 & -47.2 & -33.6 & -29.3 & -27.6 & -29.3 & -26.6 & -2.2 & -249 & -269 & -232 & \\
\hline & Lengiiapu & 5 & $\mathrm{E}_{2} \mathrm{~s}^{3}$ & 1781.2-1838.6 & -49.4 & -35.2 & -26.7 & -26.6 & -29.7 & -23.5 & 4.3 & -231 & -199 & n.d. & Huang et al., 2014 \\
\hline & Lengulapu & 13 & $\mathrm{E}_{2} \mathrm{~s}^{3}$ & 1740-1802 & -43.9 & -32.2 & -26.3 & -27.4 & -27.4 & -24.1 & 10.7 & -241 & n.d. & n.d. & \\
\hline & & 14 & $\mathrm{E}_{2} \mathrm{~s}^{3}$ & $1745-1844$ & -44.4 & -31.9 & -26.1 & -24.9 & -28.7 & -21.1 & 13.6 & -241 & n.d. & n.d. & \\
\hline & & 16 & $\mathrm{E}_{2} \mathrm{~s}^{3}$ & $1619-1746$ & -44.8 & -30.2 & -24.5 & -28.0 & -30.3 & -25.7 & 8.7 & -235 & -189 & -158 & \\
\hline & & 18 & $\mathrm{E}_{2} \mathrm{~s}^{3}$ & 1611.4-1755 & -45.0 & -30.5 & -25.1 & -26.7 & -30.9 & -23.9 & -10.4 & -234 & -187 & -159 & \\
\hline & Qijia & Q4 & $\mathrm{E}_{2} \mathrm{~s}^{4}$ & 2590 & -47.2 & -29.7 & -25.1 & n.d. & n.d. & n.d. & n.d. & n.d. & n.d. & n.d. & Chen et al., 1998 \\
\hline
\end{tabular}

Note: n.d.-not determined 
Table 4. The maximum, minimum and average values of the components, isotopes and dryness of the Paleogene natural gases in the Liaohe Basin

\begin{tabular}{|c|c|c|c|c|c|c|c|c|c|c|c|c|c|c|c|c|c|c|c|c|}
\hline \multirow{2}{*}{ Depression } & \multirow{2}{*}{ Strata } & \multirow{2}{*}{ Value type } & \multicolumn{7}{|c|}{ Natural gas component (\%) } & \multicolumn{7}{|c|}{$\delta^{13} \mathrm{C}(\%, \mathrm{VPDB})$} & \multicolumn{3}{|c|}{$\delta^{2} \mathrm{H}(\%$, VSMOW $)$} & \multirow{2}{*}{$\frac{\text { Dryness }}{\mathrm{C}_{1} / \mathrm{C}_{1-5}}$} \\
\hline & & & $\mathrm{CH}_{4}$ & $\mathrm{C}_{2} \mathrm{H}_{6}$ & $\mathrm{C}_{3} \mathrm{H}_{8}$ & $i \mathrm{C}_{4} \mathrm{H}_{10}$ & $n \mathrm{C}_{4} \mathrm{H}_{10}$ & $\mathrm{CO}_{2}$ & $\mathrm{~N}_{2}$ & $\mathrm{CH}_{4}$ & $\mathrm{C}_{2} \mathrm{H}_{6}$ & $\mathrm{C}_{3} \mathrm{H}_{8}$ & $\mathrm{C}_{4} \mathrm{H}_{10}$ & $i \mathrm{C}_{4} \mathrm{H}_{10}$ & $n \mathrm{C}_{4} \mathrm{H}_{10}$ & $\delta^{13} \mathrm{C}_{\mathrm{CO} 2}$ & $\mathrm{CH}_{4}$ & $\mathrm{C}_{2} \mathrm{H}_{6}$ & $\mathrm{C}_{3} \mathrm{H}_{8}$ & \\
\hline \multirow{9}{*}{ Eastern } & \multirow{3}{*}{$\mathrm{E}_{3} \mathrm{~d}$} & Maximum & 99.84 & 17.23 & 12.94 & 2.78 & 3.65 & 0.19 & 1.62 & -35.8 & -23.4 & -18.7 & -22.4 & -22.4 & -21.5 & 5.5 & -192 & -163 & -137 & 0.999 \\
\hline & & Minimum & 63.24 & 1.01 & 0.05 & 0.02 & 0.00 & 0.00 & 0.01 & -46.4 & -28.9 & -26.9 & -28.5 & -26.2 & -24.3 & -12.0 & -257 & -190 & -198 & 0.663 \\
\hline & & Average & 89.96 & 5.58 & 2.42 & 0.65 & 0.67 & 0.08 & 0.59 & -41.3 & -26.4 & -24.2 & -24.7 & -24.8 & -22.8 & -3.0 & -228 & -180 & -171 & 0.909 \\
\hline & \multirow{3}{*}{$\mathrm{E}_{3} \mathrm{~s}^{1}$} & Maximum & 99.51 & 11.90 & 11.83 & 7.72 & 0.91 & 0.54 & 2.75 & -34.2 & -22.3 & -21.1 & -23.5 & -21.5 & -22.9 & 0.1 & -211 & -157 & -155 & 0.995 \\
\hline & & Minimum & 73.21 & 0.00 & 0.03 & 0.01 & 0.01 & 0.00 & 0.00 & -60.7 & -47.3 & -40.3 & -27.2 & -28.9 & -25.7 & -5.3 & -261 & -246 & -203 & 0.741 \\
\hline & & Average & 93.10 & 3.61 & 2.11 & 0.85 & 0.49 & 0.16 & 0.82 & -45.4 & -30.7 & -26.9 & -25.3 & -25.5 & -23.9 & -2.8 & -233 & -195 & -175 & 0.937 \\
\hline & \multirow{3}{*}{$\mathrm{E}_{2} \mathrm{~s}^{3}$} & Maximum & 98.37 & 8.80 & 2.51 & 0.45 & 0.54 & 0.85 & 1.76 & -34.5 & -26.1 & -23.4 & -22.3 & -25.9 & -23.4 & -0.7 & -188 & -154 & -106 & 0.998 \\
\hline & & Minimum & 88.14 & 0.15 & 0.13 & 0.00 & 0.02 & 0.00 & 0.00 & -59.3 & -39.8 & -30.0 & -27.9 & -25.9 & -23.4 & -4.9 & -250 & -209 & -179 & 0.899 \\
\hline & & Average & 93.63 & 3.46 & 1.04 & 0.22 & 0.28 & 0.25 & 1.06 & -44.6 & -29.8 & -26.0 & -25.6 & -25.9 & -23.4 & -2.8 & -214 & -183 & -139 & 0.951 \\
\hline \multirow{5}{*}{ Western } & \multirow{2}{*}{$\mathrm{E}_{3} \mathrm{~s}^{1}$} & Maximum & 98.40 & 5.40 & 21.00 & 8.10 & 9.10 & 6.60 & 5.40 & -36.8 & -28.5 & -16.4 & -23.3 & -25.1 & -20.4 & 14.5 & -209 & -148 & -123 & 0.992 \\
\hline & & Average & 91.62 & 1.85 & 2.16 & 1.63 & 2.22 & 1.59 & 2.23 & -47.1 & -33.0 & -24.6 & -25.8 & -28.2 & -23.2 & 5.1 & -225 & -175 & -153 & 0.941 \\
\hline & \multirow{3}{*}{$\mathrm{E}_{2} \mathrm{~s}^{3}$} & Maximum & 97.90 & 4.80 & 6.50 & 1.00 & 1.40 & 2.00 & 6.90 & -43.9 & -30.2 & -24.5 & -24.9 & -27.4 & -21.1 & 13.6 & -225 & -187 & -158 & 0.985 \\
\hline & & Minimum & 83.40 & 1.50 & 0.00 & 0.20 & 0.30 & 0.10 & 1.90 & -49.8 & -35.2 & -29.3 & -32.5 & -32.5 & -26.6 & -10.4 & -256 & -269 & -232 & 0.878 \\
\hline & & Average & 91.07 & 2.78 & 3.02 & 0.54 & 0.87 & 0.66 & 4.40 & -46.8 & -32.2 & -26.9 & -27.4 & -29.8 & -24.3 & 2.5 & -240 & -228 & -198 & 0.929 \\
\hline
\end{tabular}




\section{Figures}

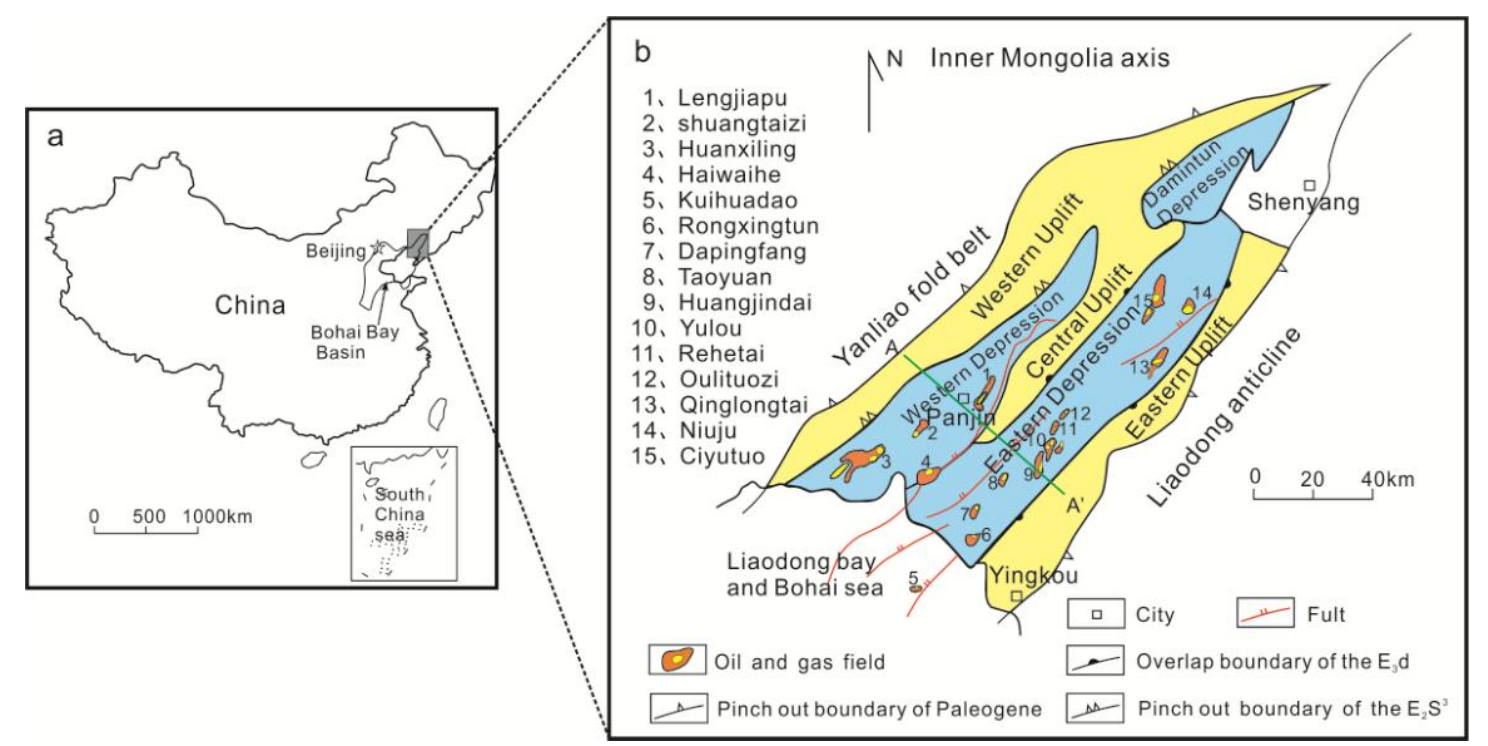

Fig. 1. Location map (a), structural subdivision and the oil-gas field distribution (b) of the Liaohe Basin (after Zhai, 1991) 


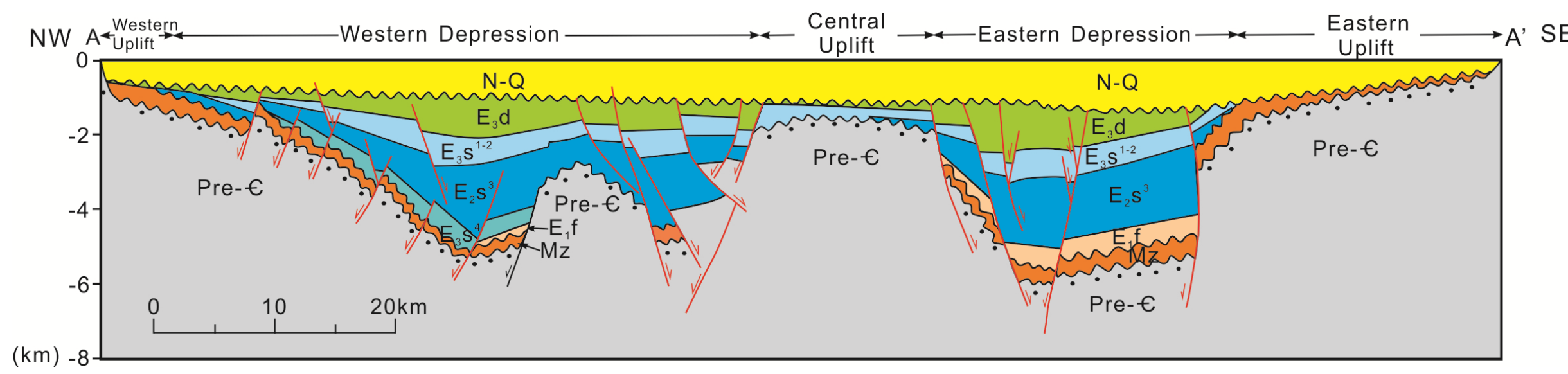

Fig. 2. Cross-section (A-A') showing the different structural of the Liaohe Basin (After Zhang et al., 1995, revised ) 

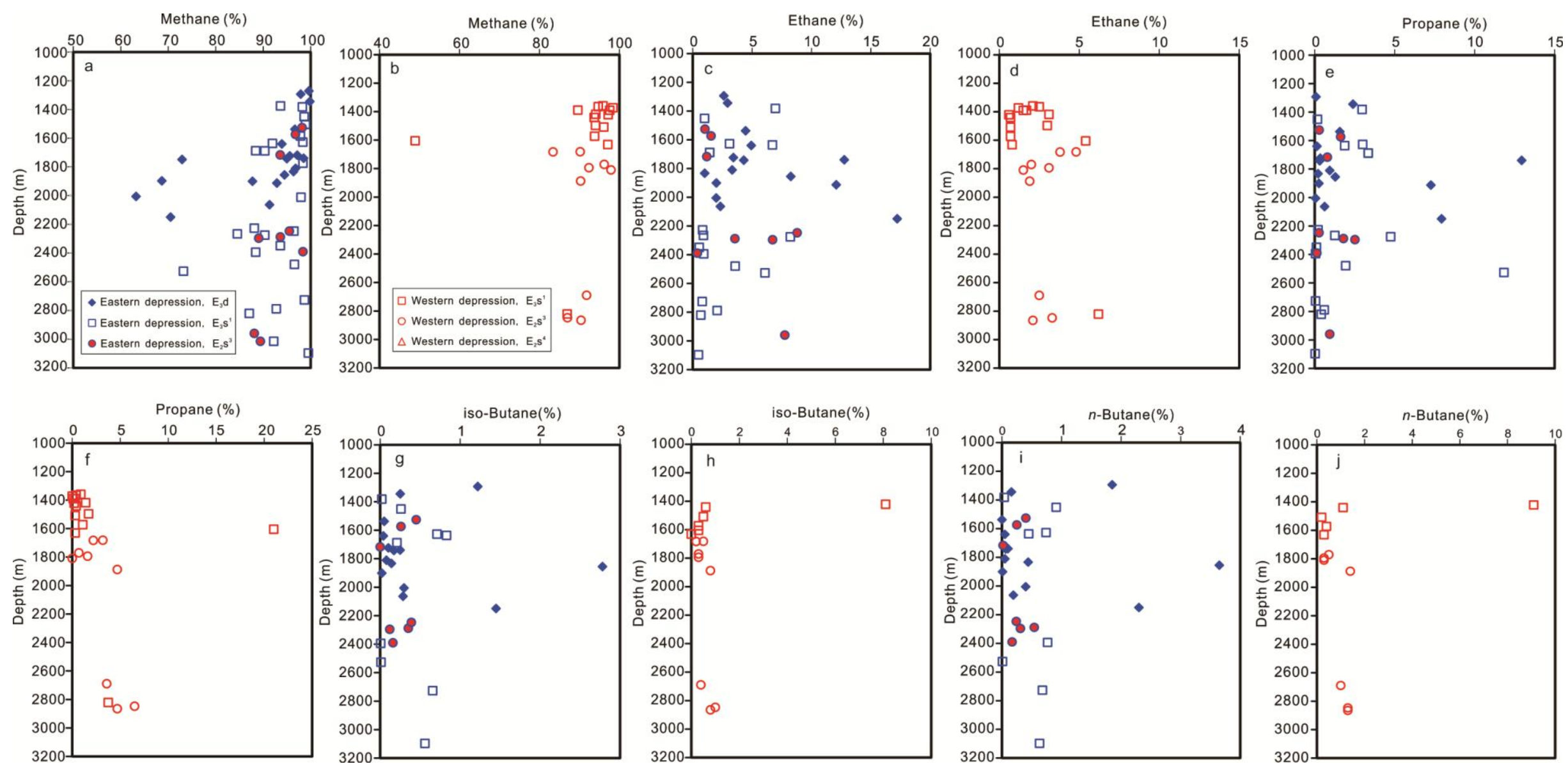

Fig. 3. Content vs. depth of the methane and it homologues of the analyzed natural gases in the Liaohe Basin (a. $\mathrm{CH}_{4}$ of the eastern depression (ED); b. $\mathrm{CH}_{4}$ of the western depression (WD); c. $\mathrm{C}_{2} \mathrm{H}_{8}$ of the ED; d. $\mathrm{C}_{2} \mathrm{H}_{8}$ of the WD; e. $\mathrm{C}_{3} \mathrm{H}_{10}$ of the ED; $\mathrm{f}_{3} \mathrm{C}_{3} \mathrm{H}_{10}$ of the WD; g. i- $\mathrm{C}_{4} \mathrm{H}_{12}$ of the ED; $\mathrm{h}$. i-C $\mathrm{C}_{4} \mathrm{H}_{12}$ of the WD; i. n- $\mathrm{C}_{4} \mathrm{H}_{12}$ of the ED j. n- $\mathrm{C}_{4} \mathrm{H}_{12}$ of the WD ) (Data sourced from Zhang et al., 1995; Cheng et al., 1998; Huang et al., 2014; Li et al., 2015; This paper). 
$\mathrm{C}_{1} / \mathrm{C}_{1.5}$

$\delta^{13} \mathrm{C}_{1}(\%$, VPDB $)$

$\delta^{13} \mathrm{C}_{2}(\%$, VPDB $)$
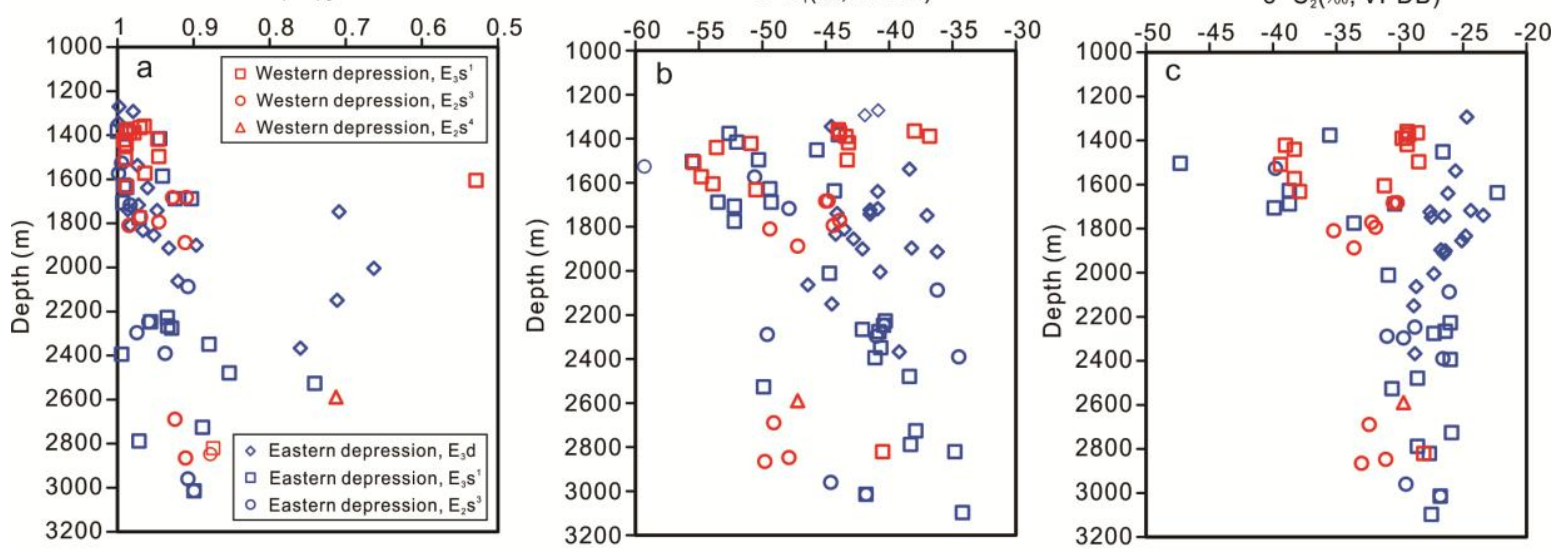

$\delta^{13} \mathrm{C}_{3}(\%$, , VPDB $)$

$\delta^{13} \mathrm{C}_{4}(\%$, VPDB $)$

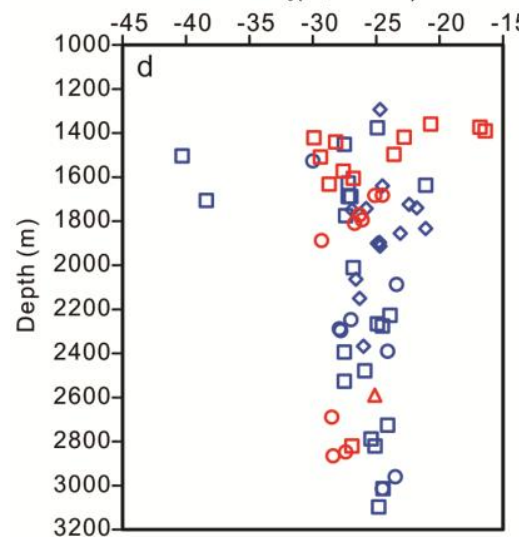

\begin{tabular}{|c|c|c|}
\hline $1000^{-7}$ & 35 & $\begin{array}{ll}-30 & -25\end{array}$ \\
\hline 1200 & e & \\
\hline $1400-$ & & 口 \\
\hline 1600 & & 焒 \\
\hline$\widehat{\xi}^{1800-}$ & & $\circ 08$ \\
\hline 2000 & & $\square$ \\
\hline ¿ 2200 & & ه \\
\hline $2400-$ & & 口 0 \\
\hline $2600-$ & 0 & \\
\hline 2800 & & 日 ه内 م م \\
\hline 3000 & & D \\
\hline
\end{tabular}

$\delta^{13} \mathrm{C}_{3}-\delta^{13} \mathrm{C}_{4}(\%$, VPDB $)$

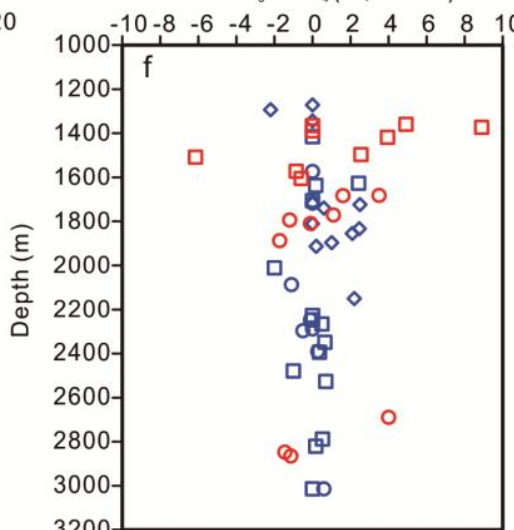

Fig. 4. Dryness and Carbon isotope values vs. depth of the methane and it homologues of the Paleogene natural gases in the Liaohe Basin (a. dryness $\left(C_{1} / C_{1-5}\right) ;$ b. $\delta^{13} C_{1} ;$ c. $\delta^{13} C_{2} ;$ d. $\delta^{13} C_{3} ;$ e. $\left.\delta^{13} C_{4} ; f . \delta^{13} C_{3}-\delta^{13} C_{4}\right)$ (Data sources as same as in Fig.3). 

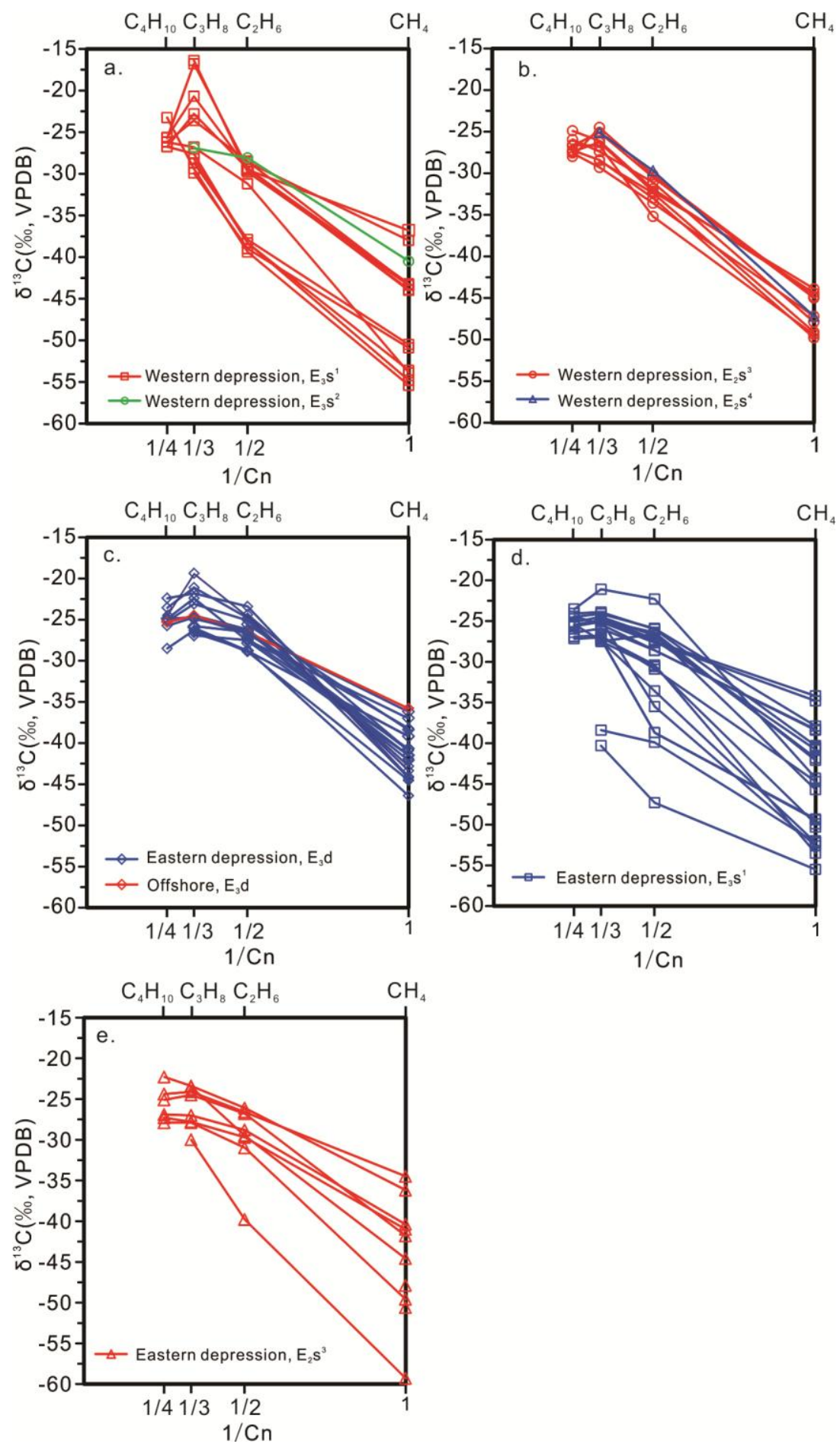

Fig. 5. Carbon isotope line of the methane and it homologues of the Paleogene natural gases in the Liaohe Basin (a.E $E_{3} d$ and $E_{3} s^{1}$ reservoirs in the WD; b. $E_{2} s^{3}$ and $E_{2} s^{4}$ reservoirs in the WD; $c$. $E_{3} d$ reservoirs of the $E D$ and offshore; $d . E_{3} s^{1}$ reservoirs in the $E D ; e . E_{2} s^{3}$ reservoirs in the ED) (diagram after Chuang et al., 1988) (Data sources as same as in Fig.3). 

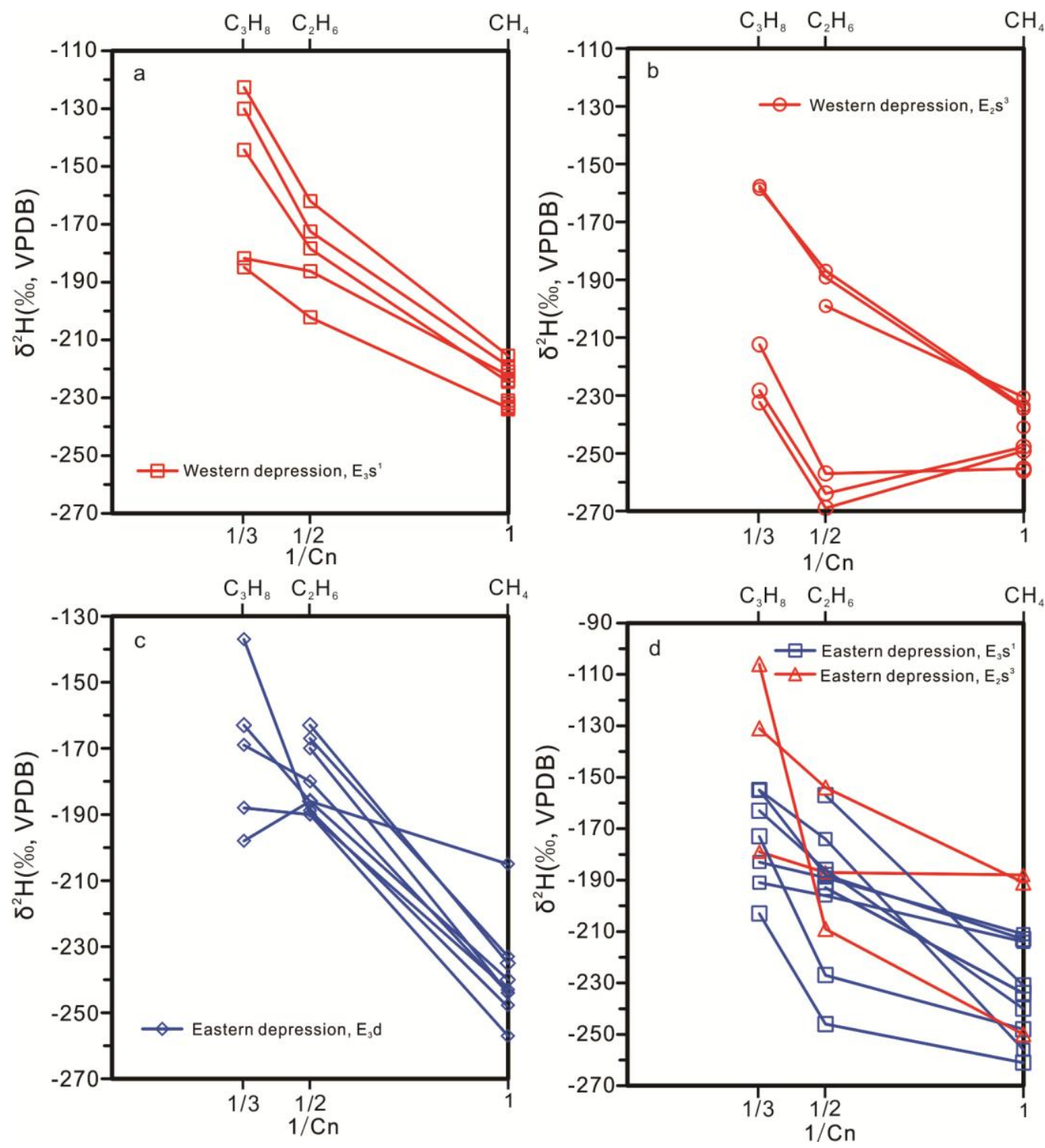

Fig. 6. Hydrogen isotope line of the methane and it homologues of the analyzed natural gases in the Liaohe Basin (a. $E_{3} s^{1}$ reservoirs in the WD; b. $E_{2} s^{3}$ reservoirs in the WD; c. $E_{3} d$ reservoirs of the ED; $d . E_{3} s^{1}$ and $E_{2} s^{3}$ reservoirs in the ED) (Data sources as same as in Fig.3). 

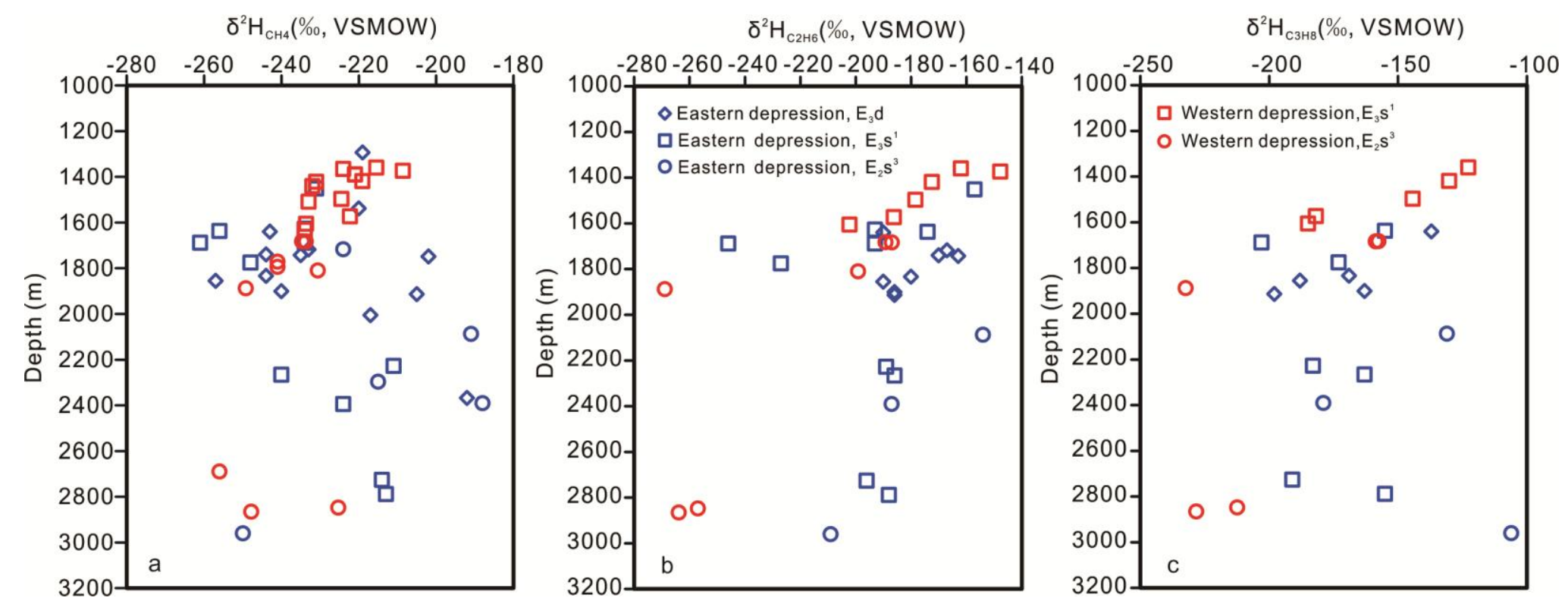

Fig. 7. Hydrogen isotope values vs. depth of the methane and it homologues of the analyzed natural gases in the Liaohe Basin (a. $\delta^{2} \mathrm{H}_{1} ;$ b. $\delta^{2} \mathrm{H}_{2}$; c. $\left.\delta^{2} \mathrm{H}_{3}\right)$ (Data sources as same as in Fig.3). 


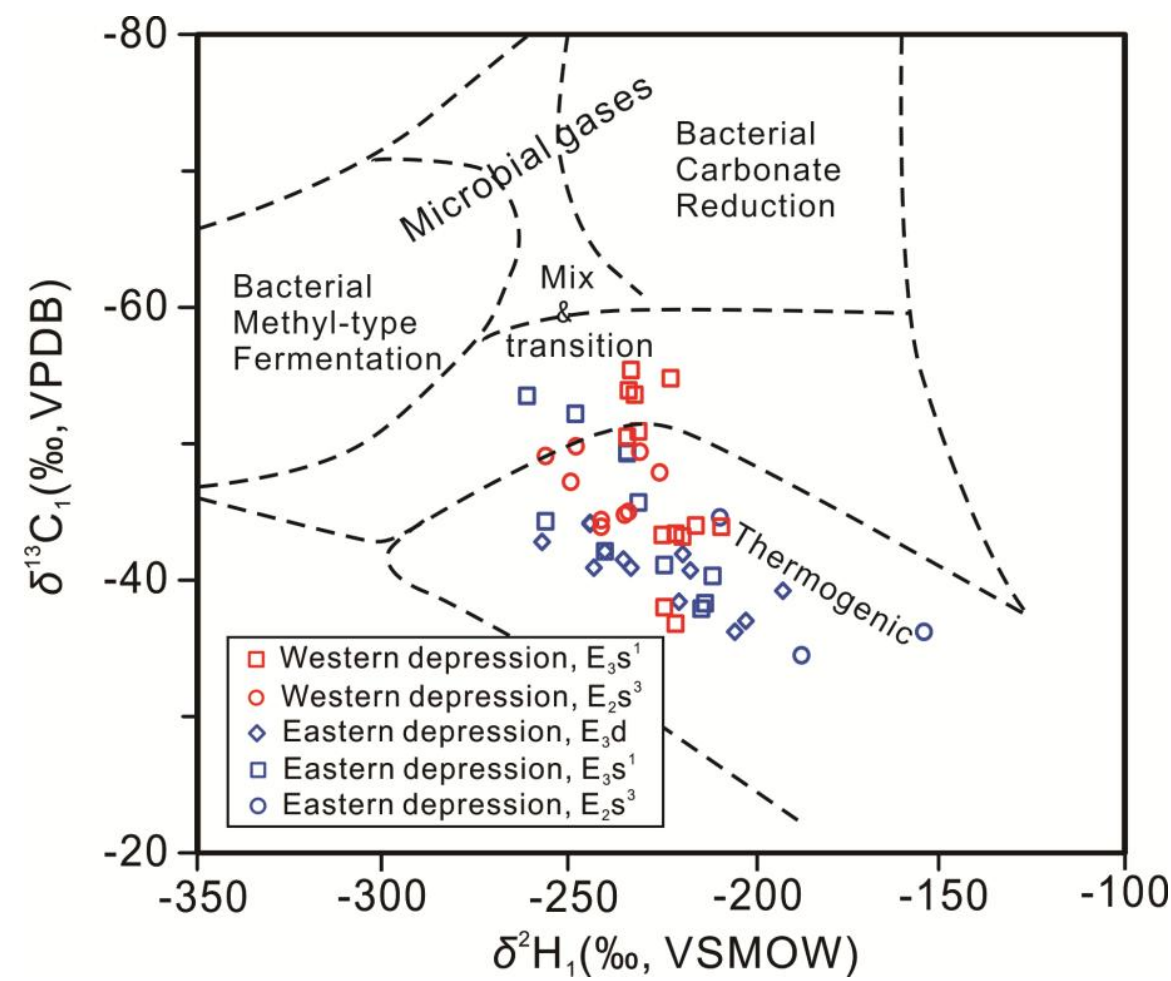

Fig. 8. Genetic characterization of analyzed natural gases using $\delta^{2} \mathbf{H}_{1}$ versus $\delta^{13} \mathbf{C}_{1}$. (Diagram after Whiticar, 1999) (Data sources as same as in Fig.3). 


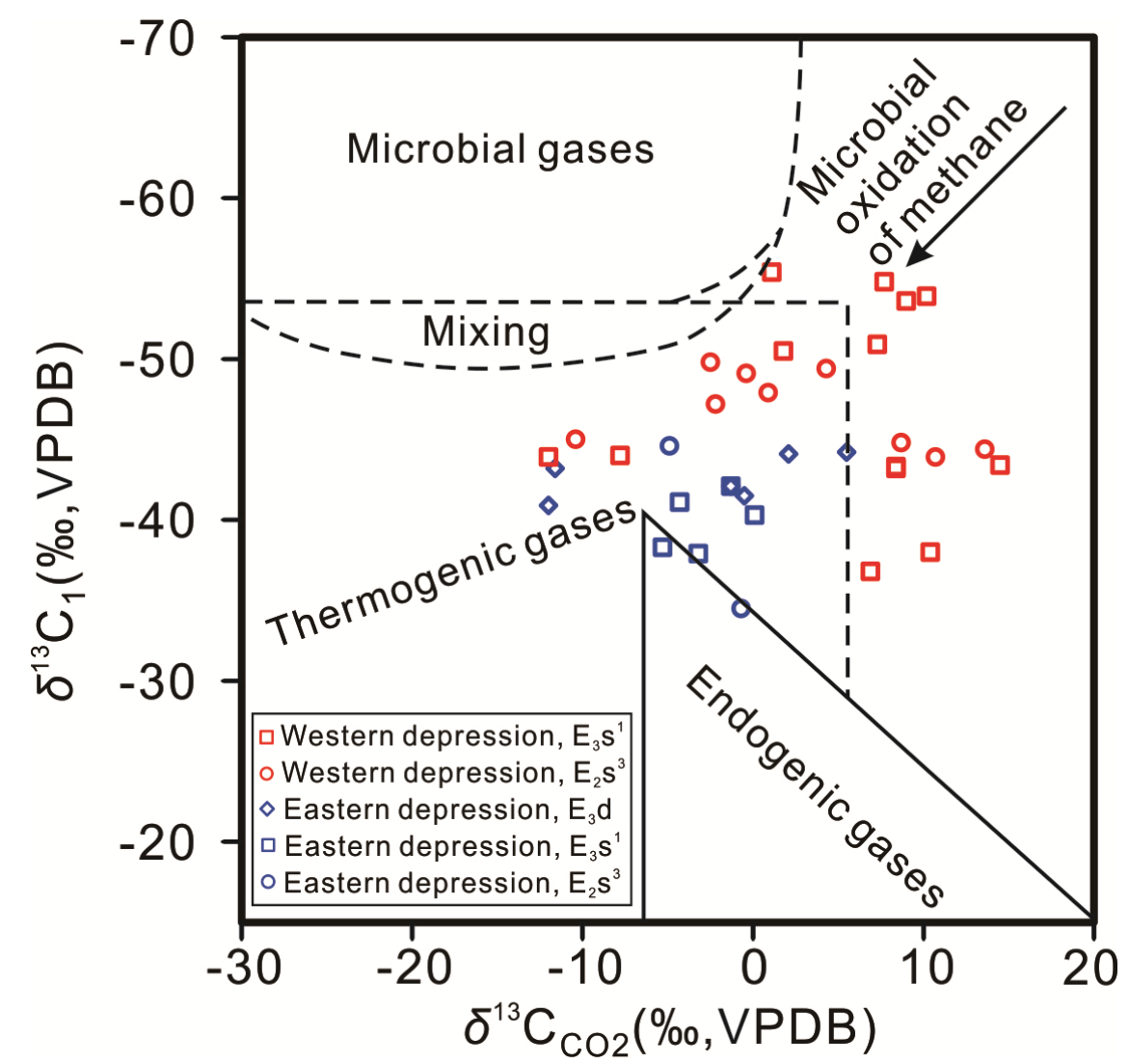

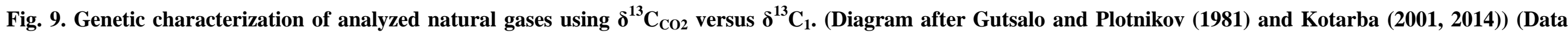
sources as same as in Fig.3). 


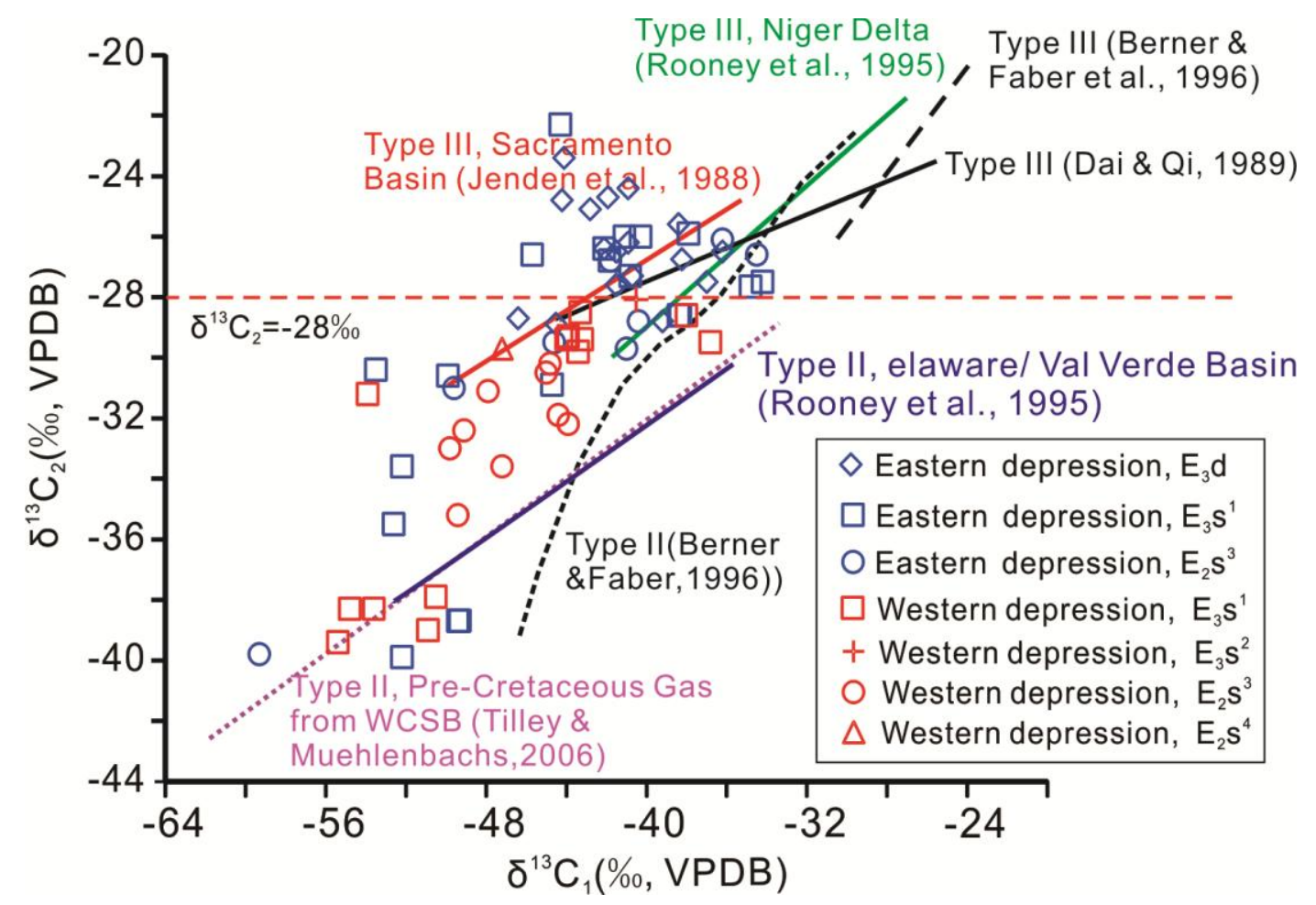

Fig. 10. ${ }^{13} \mathrm{C}_{\mathrm{CH} 4}$ versus $\delta^{13} \mathrm{C}_{\mathrm{C} 2 \mathrm{H} 6}$ cross-plot of analyzed natural gases from the Liaohe Basin. Also shown are published maturity trends of type II kerogen (Berner and Faber, 1996; Rooney et al., 1995; Tilley and Muehlenbachs, 2006) and type III kerogen (Berner and Faber, 1996; Dai and Qi, 1989; Jenden et al., 1988; Rooney et al., 1995). All the samples were plot in the top area above the line of $\delta^{13} \mathrm{C}_{\mathrm{C} 2 \mathrm{H} 6}=-28 \%$, which coincides with the gas maturity trend of the type III kerogen, indicating a coal-formed origin (Data sources as same as in Fig.3). 


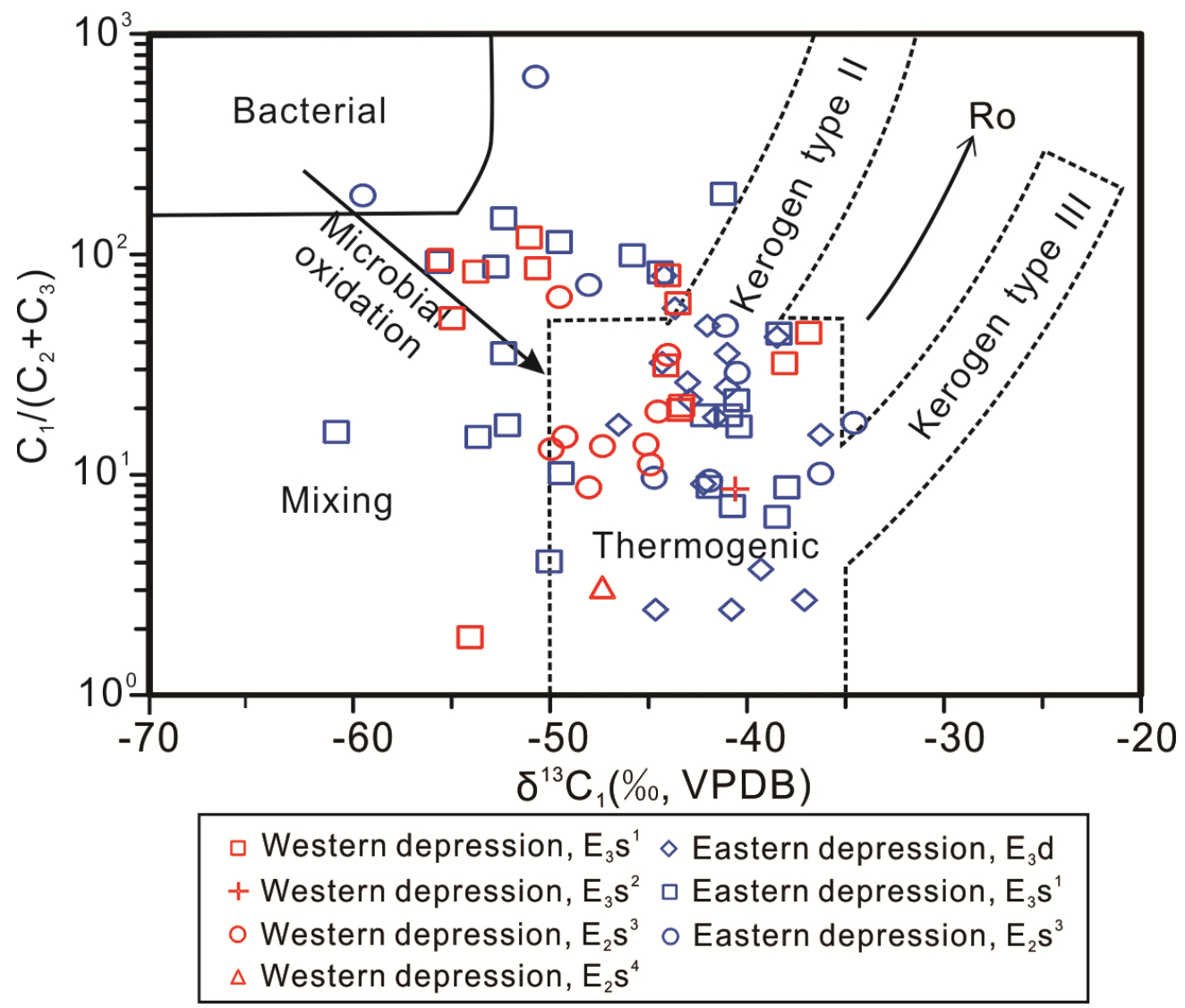

Fig. 11. Genetic characterization of analyzed natural gases using $C_{1} / C_{2+3}$ versus $\delta^{13} C_{1}$. (Diagram after Whiticar, 1999) (Data sources as same as in Fig.3). 


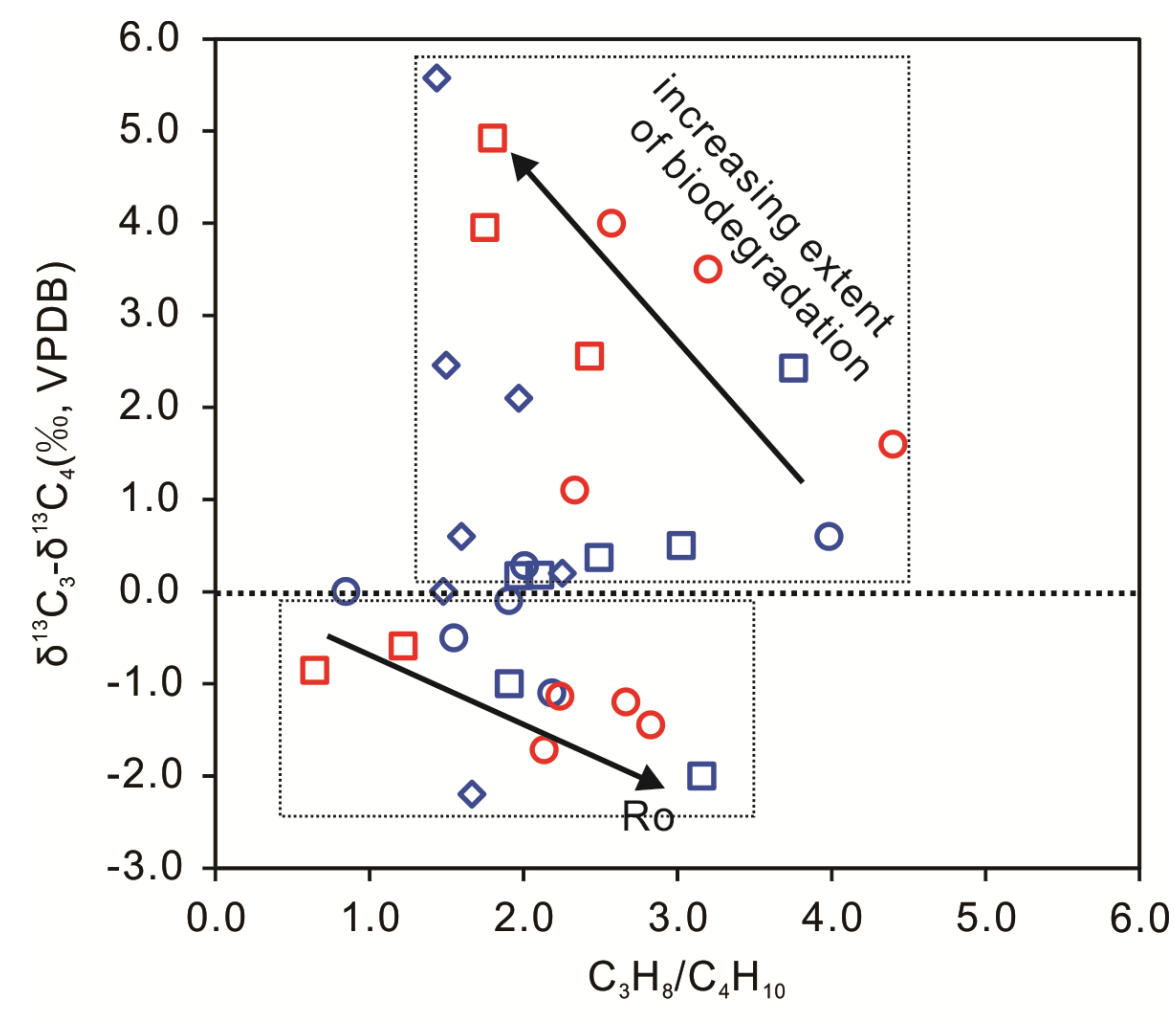

$\diamond$ Eastern depression, $\mathrm{E}_{3} \mathrm{~d} \quad \square$ Western depression, $\mathrm{E}_{3} \mathrm{~s}^{1}$
$\square$ Eastern depression, $\mathrm{E}_{3} \mathrm{~s}^{1} \mathrm{O}$ Western depression, $\mathrm{E}_{2} \mathrm{~s}^{3}$
$\mathrm{O}$ Eastern depression, $\mathrm{E}_{2} \mathrm{~s}^{3}$

Fig. 12. $\delta^{13} C_{3}-\delta^{13} C_{4}$ versus $C_{3} H_{8} / C_{4} H_{10}$ cross-plot of analyzed natural gases from the Liaohe Basin (Data sources as same as in Fig.3). 


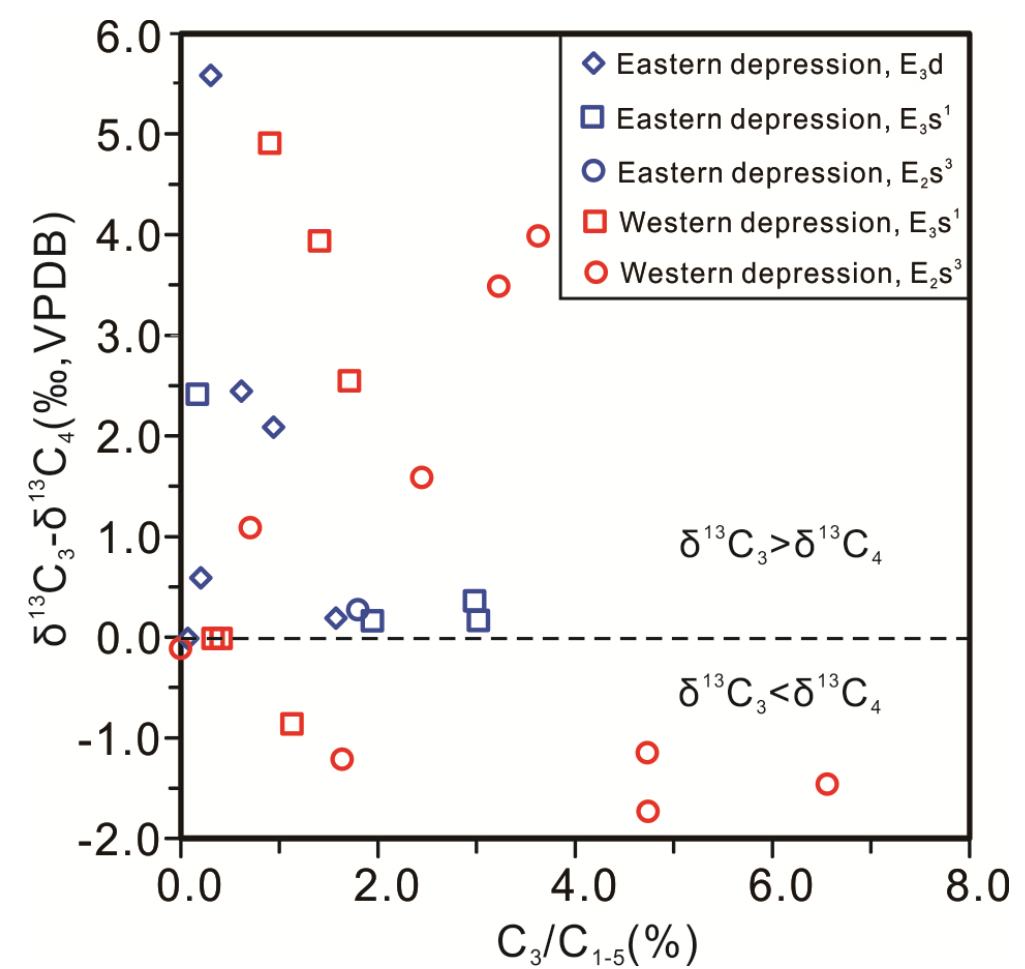

Fig. 13. $\delta^{13} C_{3}-\delta{ }^{13} C_{4}$ versus $C_{3} / C_{1-5}$ cross-plot of analyzed natural gases from the Liaohe Basin (Data sources as same as in Fig.3). 


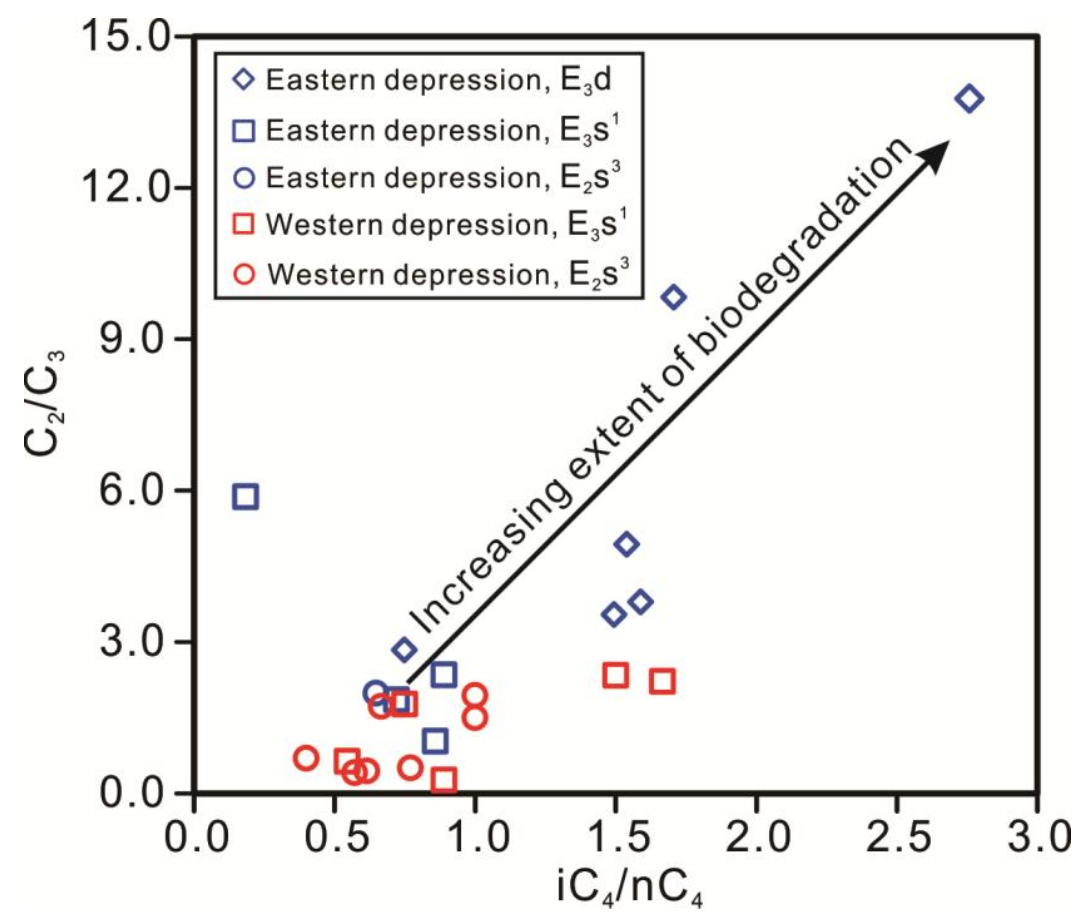

Fig. 14. $\mathrm{C}_{2} / \mathrm{C}_{3}$ versus $\mathrm{iC}_{4} / \mathrm{nC}_{4}$ cross-plot of analyzed natural gases from the Liaohe Basin (Data sources as same as in Fig.3). 

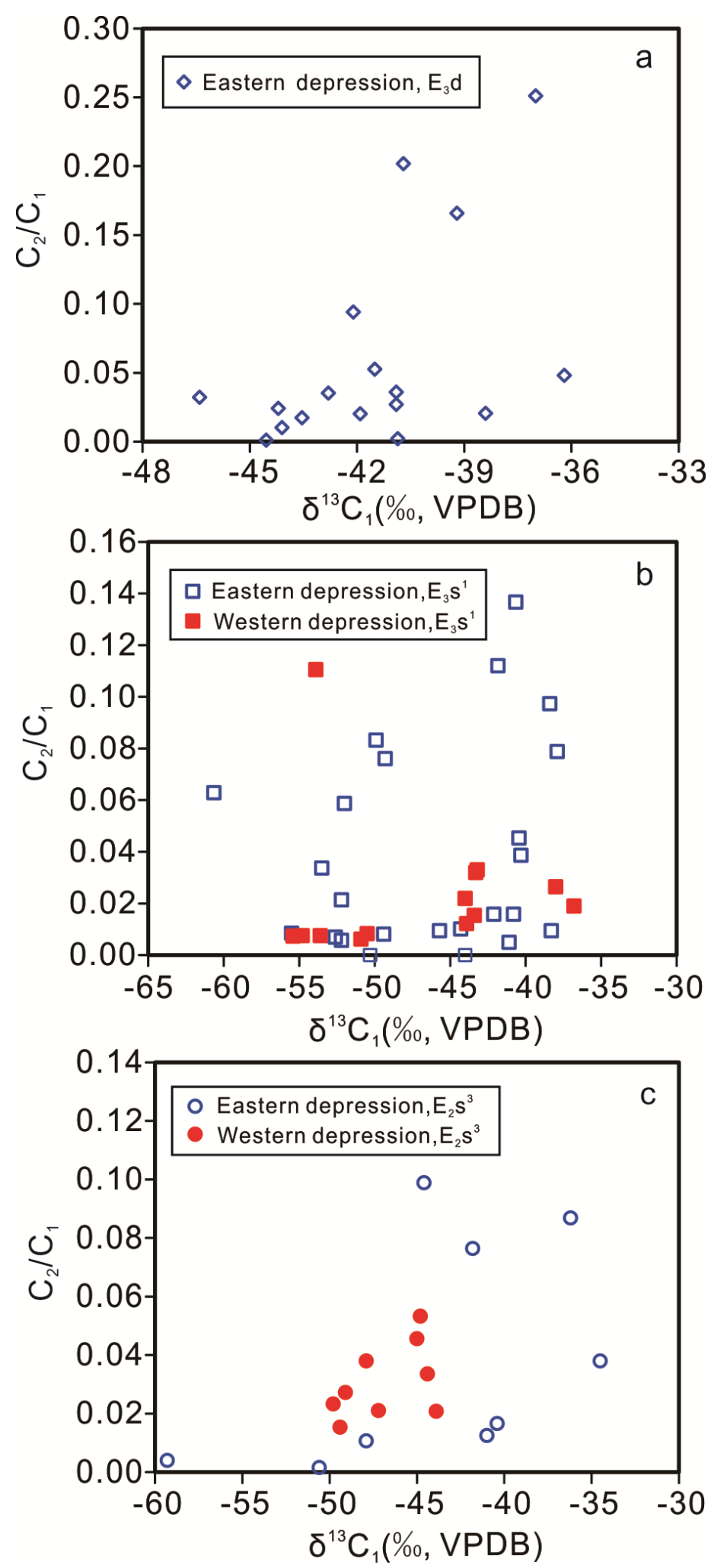

Fig. 15. $C_{2} / C_{1}$ versus $\delta^{13} C_{1}$ cross-plot of analyzed natural gases from the Liaohe Basin (a. Ed reservoir in the ED; b. $\mathrm{E}_{3} \mathrm{~s}^{1}$ reservoirs in the ED and WD; c. $\mathrm{E}_{2} \mathrm{~s}^{3}$ reservoirs in the ED and WD) (Data sources as same as in Fig.3). 


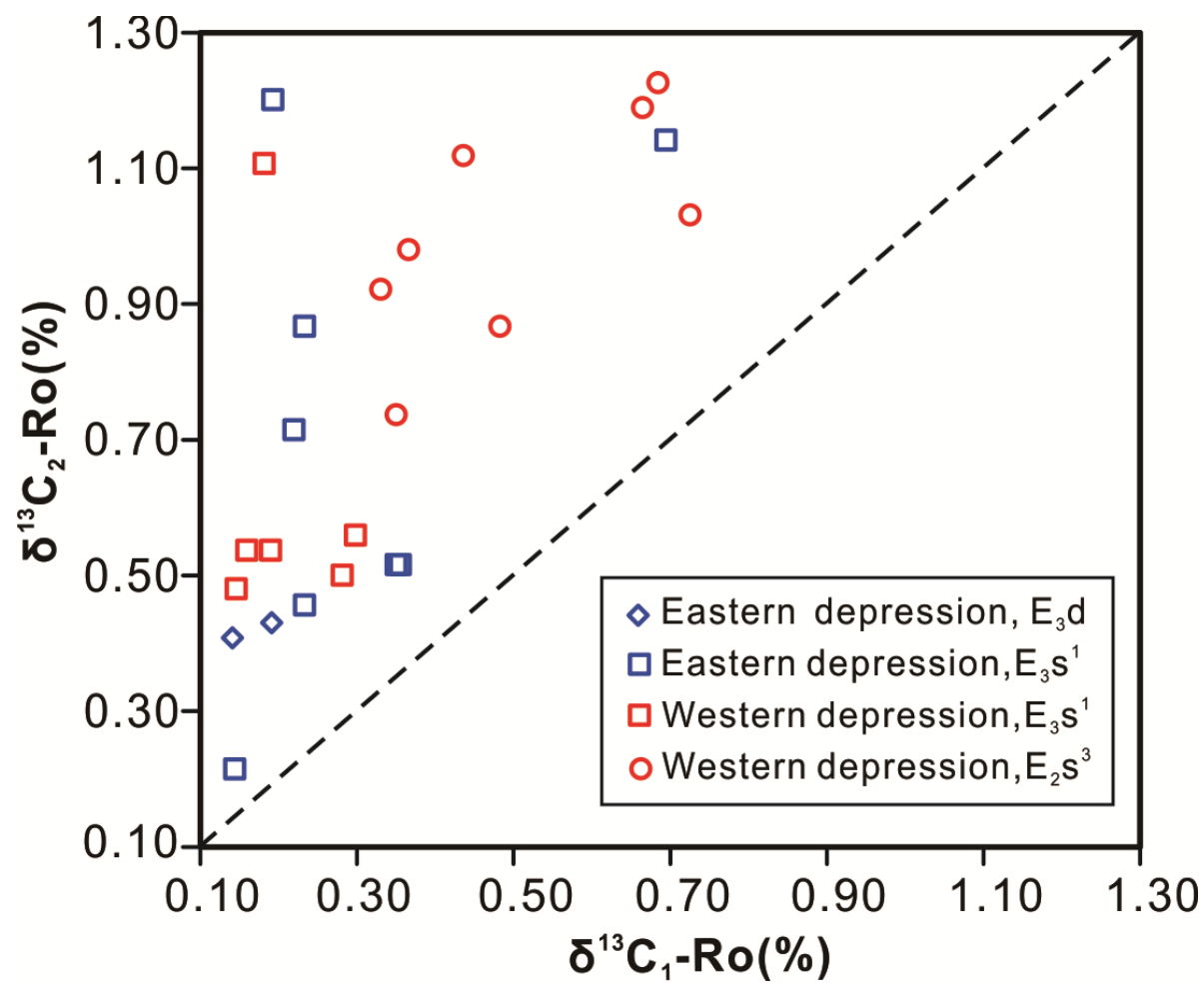

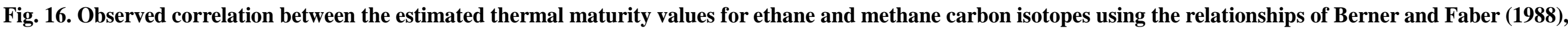
and Dai and Qi (1989). Dashed line represents a 1-1 correlation (Data sources as same as in Fig.3). 